\title{
Combined controls of sedimentology and diagenesis on seismic properties in lacustrine and palustrine carbonates (Upper Miocene, Samos Island, Greece)
}

\author{
C. Bailly ${ }^{\oplus},{ }^{1,2}$ M. Adelinet, ${ }^{1}$ Y. Hamon ${ }^{1}$ and J. Fortin ${ }^{2}$ \\ ${ }^{1}$ IFP Energies nouvelles, Geosciences Division, 1 et 4 Avenue de Bois-Préau, 92852 Rueil-Malmaison Cedex, France. E-mail: bailly@geologie.ens.fr \\ ${ }^{2}$ Laboratoire de Géologie, Ecole normale supérieure/CNRS UMR8538, PSL Research University, Paris 75005, France
}

Accepted 2019 August 3. Received 2019 August 1; in original form 2019 April 6

\begin{abstract}
SUMMAR Y
For the subsurface characterization of carbonates, linking physical properties (e.g. porosity and seismic reflectors) with their geological significance (e.g. sedimentary facies and diagenesis) is of primary importance. To address this issue, we study the lacustrine and palustrine carbonates on Samos Island through a geological and geophysical characterization of a sedimentary succession. The microstructures of the samples are described, and the samples' physical properties are measured (porosity, $P$-wave velocity and density). The results show that the identification of only the primary (i.e. sedimentary) microstructure is not sufficient for explaining the huge variations in porosity and $P$-wave velocity. Hence, we highlight two early diagenetic processes that strongly impact the microstructures and control the physical properties: (i) neomorphism occludes porosity and increases the $P$-wave velocity of mud- and grain-supported microstructures, which implies a mineralogical stabilization of the grains; (ii) conversely, the dissolution process creates porosity and decreases the $P$-wave velocity of grain-supported microstructures if the mineralogical composition of the grains is not previously stabilized. These two diagenetic processes thus depend on the primary microstructures and mineralogy of the sediments. This work aims to explain the variations in porosity and $P$-wave velocity for each defined primary microstructure. A 1-D seismogram is then built to highlight seismic reflectors with a metre-scale resolution. These reflectors are associated with several geological contrasts. Hard kicks (positive amplitude reflectors) match well with exposure surfaces related to palaeosols. They correspond to contrasts between non-modified primary microstructures and highly neomorphosed microstructures. Conversely, soft kicks (negative amplitude reflectors) are linked with diagenetic contrasts (e.g. neomorphosed microstructures versus non-modified primary microstructures) and sedimentary contrasts that can be overprinted by diagenesis (e.g. neomorphosed mud-supported microstructures versus dissolved grain-supported microstructures). This study highlights that high-resolution seismic reflectors of lacustrine and palustrine carbonates are strongly related to the spatial contrasts of primary microstructures overprinted by early diagenesis.
\end{abstract}

Key words: Microstructure; Geomechanics; Hydrology; Acoustic properties; Wave propagation; Sedimentary basin processes.

\section{INTRODUCTION}

Seismic reflectors are driven by contrasts in acoustic impedances (AI, product of $P$-wave velocity with density). For pure carbonate rocks, the $P$-wave velocity (and thus $\mathrm{AI}$ ) is mainly controlled by the porosity (Rafavich et al. 1984; Guerin \& Goldberg 1996) and its geometry (Anselmetti \& Eberli 1993; Weger et al. 2009; Fournier et al. 2018). This property is related to the "primary microstructure' acquired during the deposition of sediments (type of grains and matrix, grain packing, primary pore types and sedimentary fabric) and modified during diagenesis (bio-physicochemical evolution of microstructure after deposition, secondary pore types and diagenetic fabric) to form a 'secondary microstructure'. Indeed, the diagenetic evolution of carbonates may largely modify their primary microstructure through dissolution (creating porosity), cementation (destroying porosity) or recrystallization processes, thus impacting the physical properties such as density, elastic moduli and elastic wave velocities. The great diversity of primary and secondary 
microstructures in lacustrine carbonates (Alonso-Zarza \& Tanner $2010 a, b)$ results in a large range of physical properties that may impact their seismic expression, such as the seismic facies or potential reflectors (Soete et al. 2015).

Based on stratigraphic principles, seismic reflectors are commonly used to decipher sedimentary architectures in the subsurface ('seismic stratigraphy' of Vail et al. 1977) and describe the tectonosedimentary evolution of sedimentary basins (Mbida Yem et al. 2011). These geological concepts postulate that a laterally continuous reflector corresponds to an isochronous time line in the geological record. Nevertheless, these concepts do not consider the diagenetic evolution of carbonates, which can affect microstructures and strongly impact physical properties (Anselmetti \& Eberli 1993; Kenter et al. 1997; Eberli et al. 2003; Brigaud et al. 2010; Machek et al. 2018). Indeed, as shown by Fournier \& Borgomano (2007), cementation of porosity in carbonates increases their acoustic impedance, modifying the seismic reflectivity and thus creating reflectors that can crosscut 'stratigraphic' time lines. This diagenetic control of seismic properties known as seismic diagenesis (Davies \& Cartwright 2007) has been described for siliciclastic rocks (Avseth et al. 2000; Jarrard et al. 2000) and is also important for carbonate reservoirs because of its wide impact on seismic imaging (Wagner 1997; Fournier \& Borgomano 2007). For example, a collapsed karstic network (by-product of meteoric diagenesis) may cause disrupted and/or crosscut seismic reflectors (e.g. Hardage et al. 1996). The integration of sedimentological and diagenetic descriptions together with physical characterization is thus crucial to understanding the geological origin of acoustic properties and seismic reflectors in carbonates.

In this context, synthetic seismic modelling is a powerful tool ordinarily used to compare real seismic data with core description and wireline logging data (including sonic and density data). The goal of this tool is to be predictive of subsurface geology at a large scale (Anselmetti et al. 1997). It is also used to create seismic models of outcrop analogues and compare them to subsurface seismic data (Zeller et al. 2015; Kleipool et al. 2017; Jafarian et al. 2018). It is therefore of primary importance to be able to understand what controls the geological expression of seismic reflectors if one wants to use such models in an appropriate manner. In this paper, a highresolution characterization of the geological and physical properties of lacustrine carbonates is proposed based on the Tortonian Hora formation (Samos island) because of its well-preserved geological history. A thorough geological characterization allows us to describe the outcrop-scale structures to the microstructure of samples and identify the main diagenetic processes. Then, porosity, $P$-wave velocity and density data are measured to build a 1-D synthetic seismic model, which is compared to geological information. Finally, we discuss the main controlling parameters of the physical properties of the studied carbonates and the geological significance of the highlighted seismic reflectors.

\section{STUDY AREA AND METHODOLOGY}

The study area is located in the Mytilini Basin of Samos Island, a Greek island in the eastern part of the Aegean Sea, near Turkey (Figs 1a and b). This basin presents Upper Miocene sedimentary infill with a huge diversity of rocks (volcaniclastic, siliciclastic and carbonate rocks) distributed in four lithostratigraphic formations (from base to top: Pythagorion, Hora, Mytilini and Kokkarion Formations, according to Weidmann et al. 1984; Fig. 1c). Due to the presence of radiochronological analyses on volcanic rocks (basalt and volcaniclastic deposits), palynological study and mammal fauna description (restricted to the Mytilini formation), the age of these deposits is well constrained (Pe-Piper \& Piper 2007; Ioakim \& Koufos 2009; Koufos et al. 2011). Our study focuses on the topmost part of the Hora formation, which is composed of lacustrine and palustrine carbonates. These carbonates are located right below a major erosional surface (Hora-Mytilini transition, Fig. 1c) associated with a generalized exposure of the sedimentary system according to Weidman et al. (1984) and Stamatakis et al. (1989). This exposure may have resulted from tectonic uplift (compressive phase of Ring et al. 1999) and/or an increase in aridity causing a global drying of the lake (Owen et al. 2011). We describe a $40 \mathrm{~m}$ thick sedimentary succession on which high-resolution sampling is performed (one sample every $20 \mathrm{~cm}$ along a vertical section) to acquire physical properties alongside geological information. It should be noted that the succession is not continuous because of visibility gaps (presence of vegetation). Depending on the sample size, plugs were cored with a diameter of $23 \mathrm{~mm}$ for 81 samples and $40 \mathrm{~mm}$ for 20 samples.

A total of 52 thin sections (impregnated with blue epoxy to identify the pore space) were observed using conventional microscopy (PPL: plain polarized light, XPL: cross-polarized light). Dunham (1962) and Choquette \& Pray (1970) classifications are used to describe the limestone textures and porosity. Moreover, the main diagenetic phases are identified and organized chronologically according to their relative timing deduced during petrographic analysis (paragenesis) using cathodoluminescence microscopy (CL). Quantification of diagenetic features is performed visually (relative intensity from (0) absent to (4) intense). Additional SEM observations are performed to better characterize the morphology of micrite crystals and image the potential microporosity of a few samples.

$\mathrm{X}$-ray diffraction (XRD) is conducted on bulk powder of 50 samples to assess the mineralogy. For the preparation of samples, an agate mortar is used to avoid any contamination during grinding. We performed the measurements with a Rigaku RINT-2500 at $50 \mathrm{kV}$ and $300 \mathrm{~mA}$ using $\mathrm{Cu}-\mathrm{K} \alpha$ range radiation and a scan speed of $0.05^{\circ} 2 \theta \mathrm{s}^{-1}$. Semi-quantitative analyses of the obtained diffraction patterns are carried out using the reference intensity ratio method of MATCH! Software (Crystal Impact).

The porosity and density of the 101 plugs are measured with the triple-weight method by assessing the plug mass under three different conditions: fluid-saturated, suspended in the saturating fluid and dried. $P$-wave velocities are obtained on dry samples using $500 \mathrm{kHz}$ $P$-transductors connected to an oscilloscope. The arrival times of $P$-waves (first break) are directly measured on the oscillograph and divided by the length of the sample to calculate the $P$-wave velocity. The precision of the velocity measurements is mainly dependent on the first break picking (error $<5$ per cent). Then, porosity, density, $P$-wave velocity and AI are correlated with the sedimentary succession, and a Kernel regression is performed to highlight the vertical trends of the physical properties (smooth curves with a 95 per cent confidence interval). Finally, based on the laboratory data set, a synthetic seismic analysis is performed along the sedimentary succession (see Jafarian et al. 2018 for the equations) using EasyTrace $^{\mathrm{TM}}$ Software. Notably, unsampled zones (e.g. powdery volcaniclastic layers, clay layers and marly levels) may impact real seismic data and are not considered in our model. The acoustic impedance is calculated, and its vertical variations are used to compute the reflectivity coefficient (RC). A convolution is performed on this coefficient to create zero-offset seismic traces (1-D) using an analytical Ricker wavelet with a central frequency of $500 \mathrm{~Hz}$. Assuming a $P$-wave velocity in the range of $2000-6000 \mathrm{~m} \mathrm{~s}^{-1}$, this 

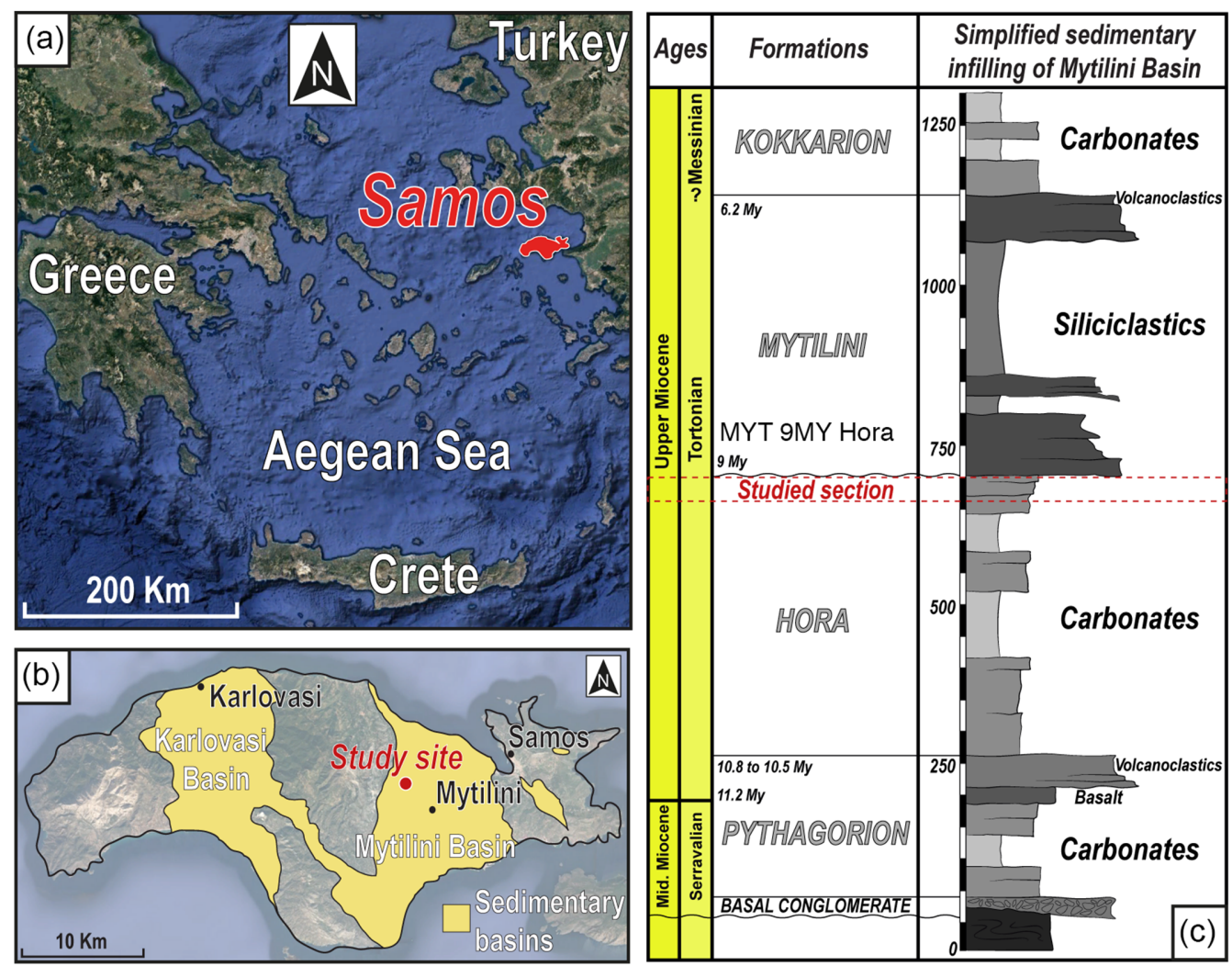

Figure 1. General framework: (a) Location of Samos Island in the Aegean Sea. (b) Sedimentary basins of Samos Island and position of the study area

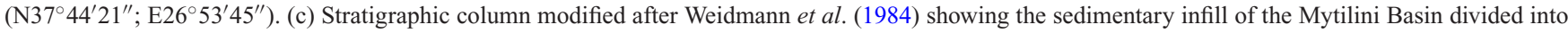
four lithostratigraphic formations. The stratigraphic location of our studied section is highlighted in red.

frequency implies a quarter wavelength criterion (wavelength/4) in the range of $1-3 \mathrm{~m}$, that is, seismic reflectors of $1-3 \mathrm{~m}$ (limit of resolvability sensu Al-Chalabi 2014), a resolution close to that obtained with crosswell seismic ( $\sim 3 \mathrm{~m}$ sensu Harris et al. 1995). This resolution aims at characterizing metre-scale impedance contrasts.

\section{MICROSTRUCTURES, SEDIMENTARY SETTING AND PHYSICAL DATA SET}

\subsection{Microstructures of samples}

\subsubsection{Description of primary microstructures and mineralogical composition}

Four different primary microstructures are identified within the limestones (Fig. 2a). Clotted mudstone and wackestone samples (M1, Fig. 2a-1) contain mainly microporous peloids (spherical to ovoid structureless micritic carbonate grains) embedded in a micritic matrix (calcite crystals with a size less than to $4 \mu \mathrm{m}$ ). These samples contain an intercrystalline microporosity, localized between the subrounded micrite crystals (Fig. 2c1-2-3) and a few mouldic pores (dissolution of peloids). They have mineralogy close to pure calcite $\left(\mathrm{CaCO}_{3} \sim 99\right.$ per cent; Table 1). Peloidal packstone samples (M2; Fig. 2a-2) present a grain-supported fabric. Their micritic matrix as well as the peloids and ooids are microporous. They show a nearly pure calcite mineralogy $\left(\mathrm{CaCO}_{3} \sim 98\right.$ per cent; Table 1). Grainstone samples (M3; Fig. 2a-3) contain a high proportion of peloids, a few bioclasts, a few quartz grains and some micritized ooids. In these samples, the grains are embedded in a sparitic cement (calcite crystals with a mean size of $20 \mu \mathrm{m})$. They are composed of pure calcite $\left(\mathrm{CaCO}_{3} \sim 99\right.$ per cent; Table 1$)$ except for two samples that present a higher proportion of siliciclastic material (clay, quartz and a few feldspars). Finally, silty packstone (M4; Fig. 2a-4) contains gastropods, ostracods, many microporous peloids and silt-sized quartz embedded in a microporous micritic matrix. Clay nodules are identified in thin sections, as is an intraparticle porosity partially filled by a calcite cement. Obviously, these silty packstones exhibit a non-negligible amount of siliciclastic material $\left(\mathrm{CaCO}_{3} \sim 95\right.$ per cent; Table 1$)$. Two other non-limestone rocks are recognized in the studied sedimentary succession: marls and volcaniclastic layers. Given their lithology, it was not possible to realize any sampling in these layers, and they were not studied in this paper.

\subsubsection{Description of secondary microstructures modified by diagenesis}

The different primary microstructures described above show evidence of diagenetic modifications (Figs $2 b$ and $c$ ). The main diagenetic phases identified are organized chronologically (paragenesis in Fig. 3a). During sedimentation, grain micritization could occur (sensu Purser 1980). It consists of micrite envelopes that develop around grains and may completely obliterate the primary grain structure (e.g. gastropods, ostracods and ooids, see examples in Figs $2 b-4$ and 3b-1). This process may be due to micro-boring by endolithic algae around the grains, infilled by low-magnesian calcite (a stable mineralogy; Swirydczuk et al. 1979). In addition, for ooids and peloids primary made of aragonite or high-magnesian calcite 

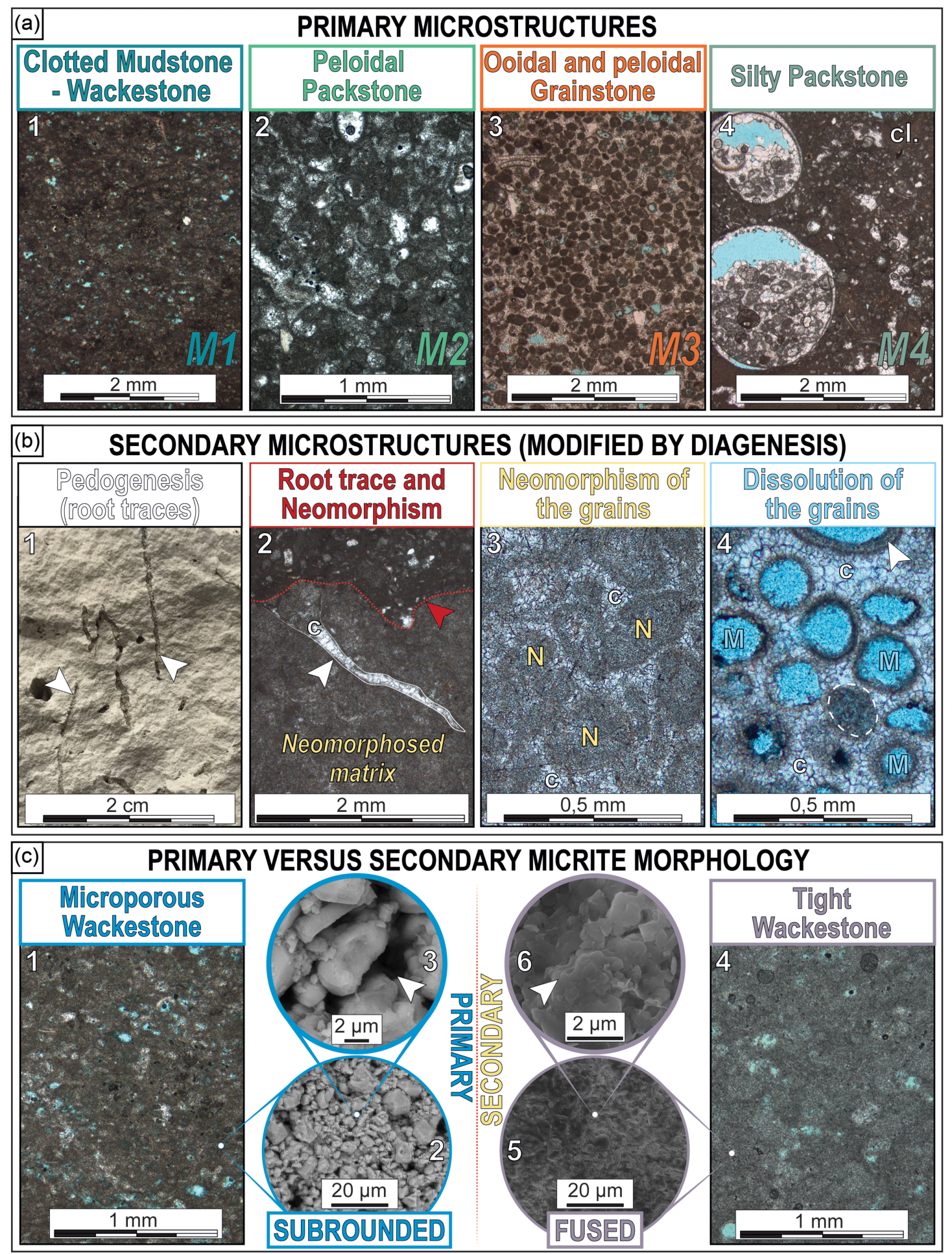

Figure 2. (a) Illustration of the different primary microstructures (porosity is in blue): 1. Microscopic PPL view of a clotted mudstone-wackestone with few peloid moulds; 2. Microscopic PPL view of a packstone showing peloids, ooids, and partially cemented porosity; 3. Microscopic PPL view of a grainstone showing ooids and peloids embedded in sparitic cement; 4. Microscopic PPL view of a packstone with gastropods, peloids and clay nodules (cl.). (b) Secondary microstructures modified by diagenesis (porosity is in blue): 1. Macroscopic view of root traces (white arrows) in a wackestone sample; 2. Microscopic PPL view of an exposure surface (red arrow) associated with a cemented root trace (white arrow, c) and a neomorphosed mottled matrix; 3 . Microscopic PPL view of a grainstone with neomorphosed peloids $(\mathrm{N})$ and interparticle cement (c); 4. Microscopic PPL view of mouldic pores (M) in a grainstone, indicating the dissolution of ooids and peloids. Note also the micritization of ooids (white arrow). A partially dissolved peloid is highlighted with a white dashed circle. (c) Primary versus secondary micrite morphology. 1. Enlarged microscopic view of a microporous wackestone showing a brownish matrix. 2. SEM view of the microporous matrix composed of subrounded micrite. 3. Magnified view of subrounded micrite crystals (a micropore is indicated by the white arrow). 4. Enlarged microscopic view of a tight wackestone showing a whitish matrix. 5. SEM view of the tight matrix composed of fused micrite. 6 . Magnified view of fused micrite crystals (coalescence of micrite is indicated by the white arrow). 
Table 1. Calcite content of 50 samples grouped by microstructures. The means and standard deviations of microstructures 1,2 and 3 present the highest content of calcite (always $>97$ per cent), whereas microstructure four shows a slightly lower calcite content ( $<95$ per cent).

\begin{tabular}{lcccc}
\hline $\begin{array}{l}\text { Calcite content } \\
\text { percent) }\end{array}$ & Microstructure $1(n=17)$ & Microstructure $2(n=5)$ & Microstructure $3(n=23)$ & Microstructure $4(n=5)$ \\
\hline Mean & $\mathbf{9 9}$ & $\mathbf{9 8}$ & $\mathbf{9 9}$ & $\mathbf{2}$ \\
StDeva & $\mathbf{1}$ & $\mathbf{1}$ & $\mathbf{9 4}$ & $\mathbf{2}$ \\
Minimum & $\mathbf{9 6}$ & $\mathbf{9 6}$ & $\mathbf{9 2}$ & $\mathbf{9 0}$ \\
Maximum & $\mathbf{1 0 0}$ & $\mathbf{9 9}$ & $\mathbf{1 0 0}$ \\
\hline
\end{tabular}

(an unstable mineralogy), micritization may allow preservation of a possible subsequent dissolution (Fig. 3b-1). This process only affects packstone and grainstone microstructures. At the macroscale, either in the field or in samples, root traces can be identified, which suggests pedogenesis associated with exposure, a typical process of palustrine environments (Alonso-Zarza 2003; Fig. 2b-1). Below these exposure surfaces associated with root traces, the microstructure is highly modified by neomorphism (sensu Folk, 1965), which is the earliest diagenetic process of post-depositional paragenesis (Fig. 3a). Neomorphism is characterized by recrystallization and possible mineralogical stabilization of unstable mineralogy (Fig. 2b2-3). For mudstones and wackestones, neomorphism enhances the overgrowth and cementation of the micrite crystals of the matrix (fused micrite in Fig. 2c-5-6), while for grainstones, this process increases crystal sizes of peloids and micritized ooids (Fig. 2b-3). As a general observation, neomorphism induces a decrease in porosity. Under CL, the neomorphosed grains appear non-luminescent (Fig. 3b-2-3). If neomorphism is absent, dissolution of the unstable carbonate grains could occur subsequently (Fig. 3a), creating mouldic porosity ( $\mathrm{M}$ on Fig. 2b-4). This dissolution phase mainly affects grainstones (Fig. 2b-4) and increases the porosity. Different intensities of dissolution are observed, from a nearly complete dissolution ( $\mathrm{M}$ of Fig. 3b-4) down to micromouldic pores ( $\mu \mathrm{M}$ of Fig. 3b-5). After dissolution, a microgranular cement (crystal sizes of $10-20 \mu \mathrm{m}$ ) partially occludes the porosity, affecting mainly the peripheries of the grains together with the inner part of previously dissolved grains (Fig. 3b-6-7). Under CL, this cement is subdivided into two growth stages, a first one that is non-luminescent and a second one that is bright orange ( $\mathrm{C} 1$ and $\mathrm{C} 1 \mathrm{~b}$, respectively, in Fig. 3b7-11). Then, evidence of minor compaction is observed in grainstones (Fig. 3a). The grainstones exhibit a compacted arrangement of grains with punctual concavo-convex contacts highlighted by the microgranular cement remnants (Fig. 3b-8-9). Finally, a sparitic cement (Fig. 3a and c on Fig. 2b) may partially or totally occlude the interparticle porosity, intraparticle porosity and mouldic porosity. This cement exhibits two growth stages, a first dull orange stage and a second non-luminescent stage ( $\mathrm{C} 2$ and $\mathrm{C} 2 \mathrm{~b}$, respectively, in Fig. 3b-10-11). The combination of the primary microstructures and the diagenetic modifications implies a large diversity of final (secondary) microstructures that can have an impact on the physical properties (porosity, density and $P$-wave velocity).

\subsection{Depositional environments}

Based on the identification of the different microstructures (Fig. 2) and the description of their vertical stacking and lateral extent (Fig. 4), we built a simple depositional model for our study case, which is divided into three different domains (Fig. 5). Our model mimics the ramp-type lake margin of Platt \& Wright (1991).

First, a low energy distal to marginal domain is proposed. It is represented by peloidal mudstones and wackestones, without any hydrodynamic-related sedimentary structures (M1; Fig. 2). Laterally, a moderate to high energy marginal domain is identified. It is associated with peloidal packstones and grainstones (M2 and M3; Fig. 2). Some grainstone beds exhibit an erosional base, oolites and angular quartz grains (interpreted as clastic supply by fluvial inputs). The grain-supported fabric, bedding and allochems suggest moderate to high hydrodynamism. Fluvial inputs are characterized by the presence of silt-sized quartz in the lake, allowing the deposition of silty packstones (M4; Fig. 2). Finally, a palustrine domain is recognized and corresponds to lacustrine carbonates that show evidence of repeated exposure (Figs 2-4). The occurrence of root traces strongly suggests pedogenic activity that may impact the primary microstructures. Laterally from these palustrine carbonates, a floodplain domain allows the accumulation of metre-thick clayey to marly layers. It should be noted that volcaniclastic layers can also occur within the sedimentary succession, suggesting volcanic activity during deposition, as previously outlined by Pe-Piper \& Piper (2007), Owen et al. (2011) and Weidmann et al. (1984).

\subsection{Description of the vertical evolution of microstructures and physical properties}

The different microstructures described previously are compared with the physical properties of samples (Fig. 6). The lower $5 \mathrm{~m}$ of the succession are mainly composed of highly stratified clotted mudstones and wackestones and are capped by $2 \mathrm{~m}$ of grainstones (see panel 1 of Fig. 4). A thick volcaniclastic layer is identified between 6.8 and $7.8 \mathrm{~m}$ and marks a transition to an alternation of decametric to pluricentimetric beds of wackestones, packstones and grainstones (until $14 \mathrm{~m}$, panels 2 and 3 of Fig. 4). These beds display some episodic exposure surfaces expressed by root traces and neomorphism $(8.2,10.2$ and $12.2 \mathrm{~m})$, which correspond to the red lines in panels 2 and 3 in Fig. 4. Some metric beds of grainstones are observed between 23 and $29 \mathrm{~m}$, separated from each other by visibility gaps. Between 32 and $34 \mathrm{~m}$, the sedimentary succession is mainly composed of grainstones. These levels are capped by $2 \mathrm{~m}$ of mudstones and wackestones associated with a high density of root traces ( 34 to $36 \mathrm{~m}$ ). From $36 \mathrm{~m}$ to the top of the succession, sedimentary pattern changes and metric marly levels are identified between packstone beds.

The corresponding vertical evolution of physical properties shows high variability, with porosity ranging between 5 and 35 per cent (Fig. 6b), $P$-wave velocity ranging between 2800 and $5600 \mathrm{~m} \mathrm{~s}^{-1}$ (Fig. 6c), and dry density ranging between 1.75 and $2.60 \mathrm{~g} \mathrm{~cm}^{-3}$ (Fig. 6d). To explain this large variability, the identification of only the primary microstructure is not sufficient, and the relative intensity of neomorphism and dissolution is therefore indicated ('diagenetic features'; Fig. 6a). For the first 5 m, these two diagenetic features seem to moderately affect the microstructure, and intermediate values of porosity are observed (approximately 18 per cent). Between 5 and $10 \mathrm{~m}$, dissolution largely dominates and is associated with the highest values of porosity ( $\sim 35$ per cent). Then, 

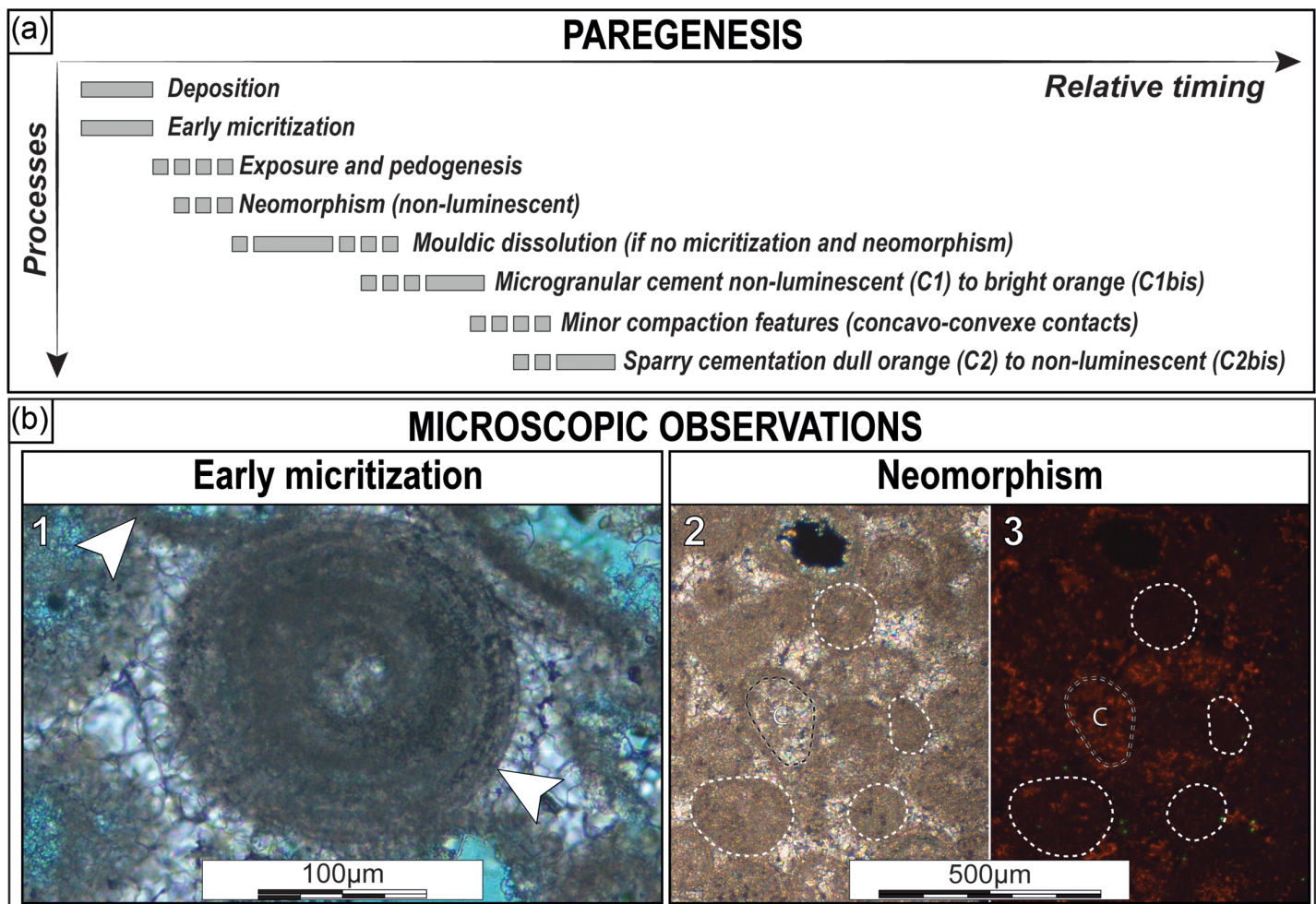

OBSERVATIONS
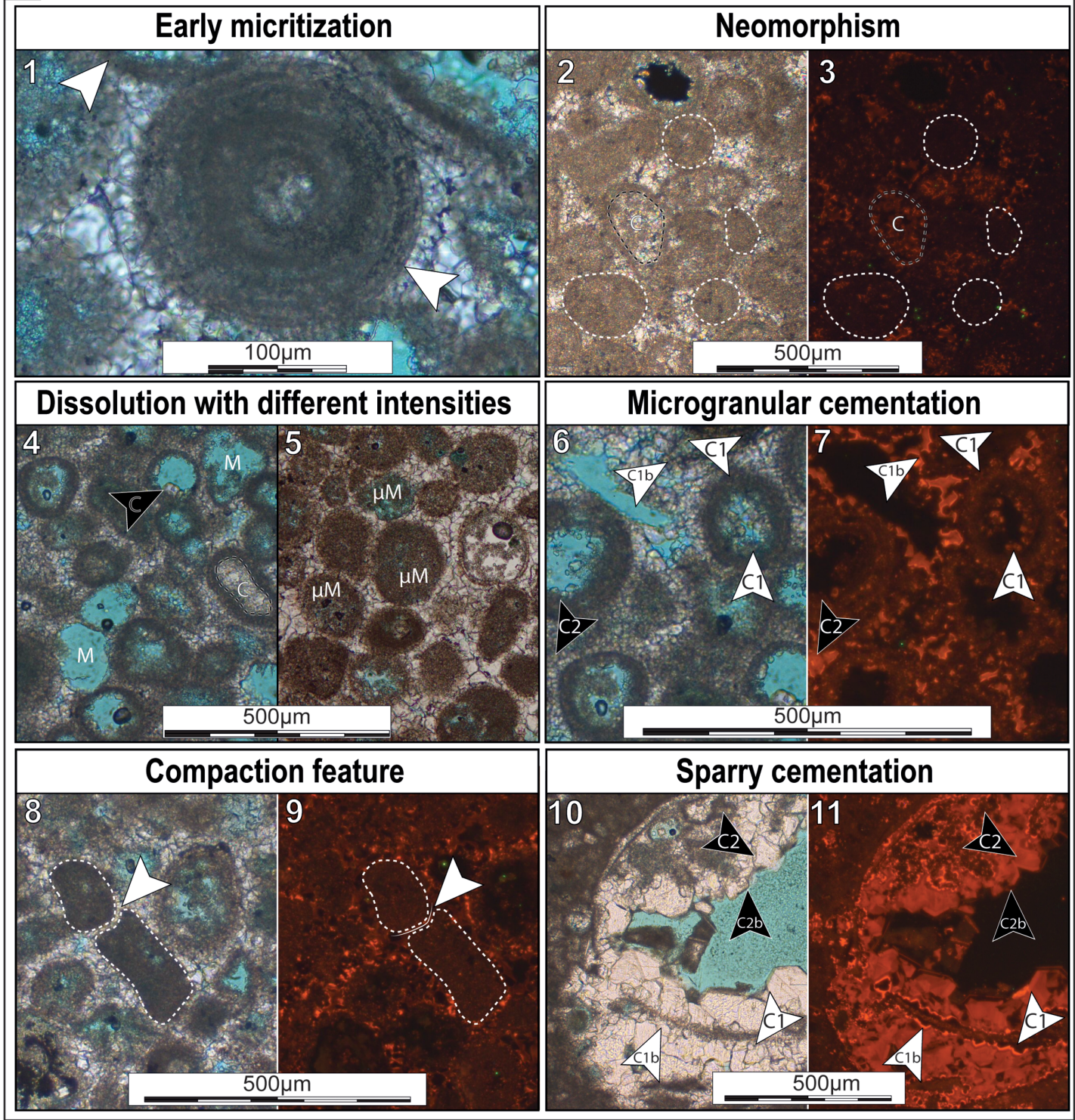

Figure 3. (a) Paragenetic sequence highlighting the relative timing of the different diagenetic processes that modify the primary microstructures. (b) Microscopic observations of the different diagenetic processes: 1. Microscopic PPL view of a micritized oolite observed within a peloidal and ooidal grainstone. White arrows indicate the micritized envelopes. 2. Microscopic XPL view of neomorphosed ooids and peloids within a grainstone sample (examples indicated by dashed with circles). Note the presence of a cement (named 'C') inside a pre-existing mouldic pore. 3. Corresponding microscopic CL view showing that the neomorphosed ooids and peloids do not show any luminescence but that the cement is luminescent. 4. Microscopic PPL view of a high intensity of mouldic pores (M) within a grainstone. Note again the occurrence of a cement within pre-existing moulds. 5. Microscopic PPL view of the low intensity of micromouldic pores $(\mu \mathrm{M})$ within a grainstone. 6. PPL view and 7. Corresponding CL view of a grainstone highlighting an early microgranular cement that is non-luminescent $(\mathrm{C} 1)$ and bright orange $(\mathrm{Clb})$. 8. PPL view and 9. CL view of a concavo-convex contact between microporous peloids (dashed white circle), highlighted by the microgranular cement (white arrow). 10. PPL view and 11. Corresponding CL view of a grainstone highlighting a microgranular cement $(\mathrm{C} 1$ and $\mathrm{C} 1 \mathrm{~b})$ and a sparry cement that is dull orange $(\mathrm{C} 2)$ to non-luminescent $(\mathrm{C} 2 \mathrm{~b})$. 

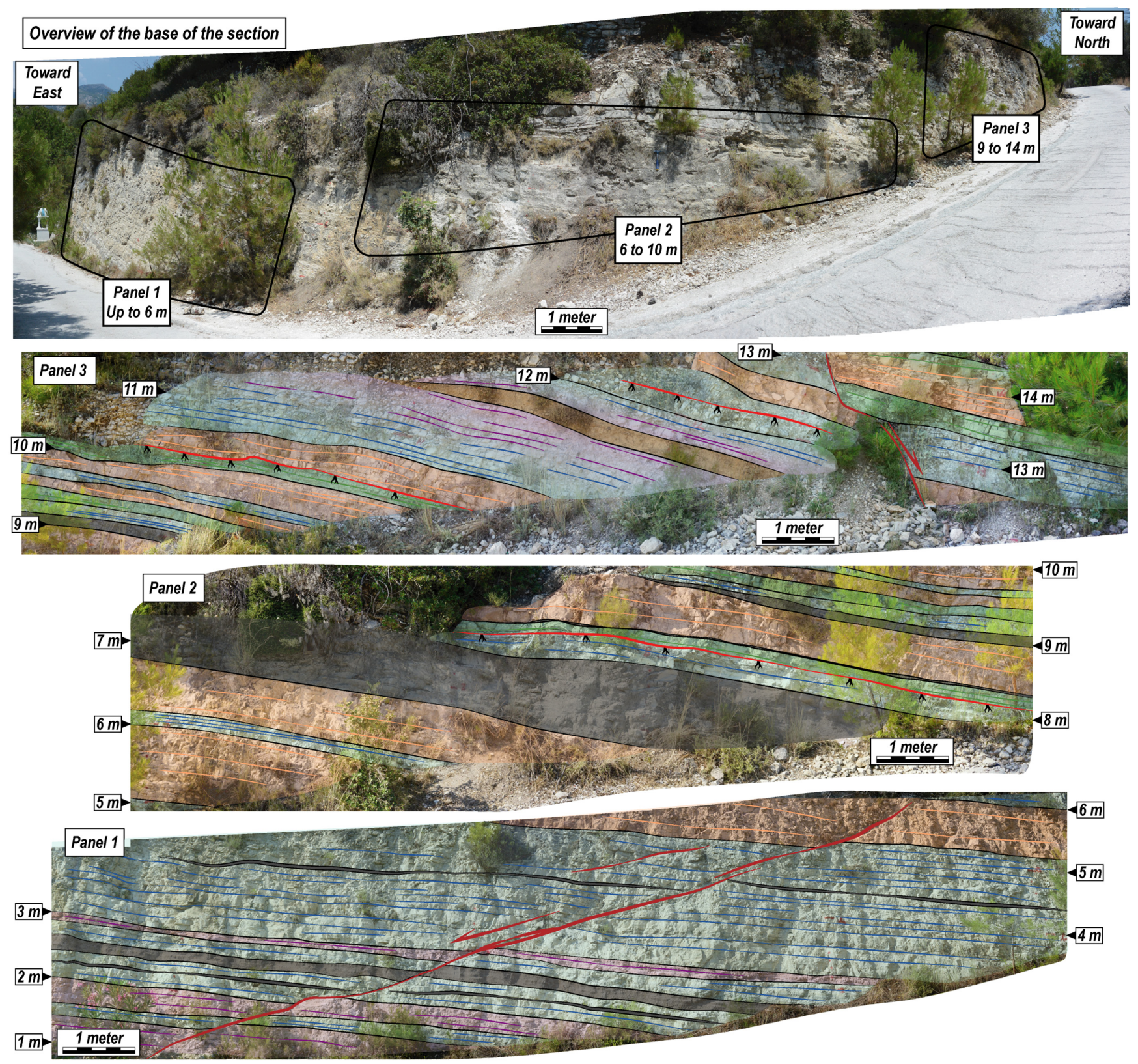

Figure 4. Overview of the base of the studied section. Panels 1, 2 and 3 display the different primary microstructures described previously (mudstones in purple, wackestones in blue, packstones in green, grainstones in orange, volcanic ash layers in grey and marls in brown). Colour lines inside each texture symbolize the stratification. Exposure surfaces combined with soil development are highlighted with red lines. Note the presence of a few normal faults that could induce centimetric to metric displacements. The vertical scale is the same as in Fig. 6.

neomorphism increases between 10 and $12 \mathrm{~m}$, whereas dissolution decreases, as does the porosity (from 35 per cent to 7 per cent). From 12 to $14 \mathrm{~m}$, the intensity of the neomorphism and dissolution processes fluctuates, as does the porosity (between 15 per cent and 25 per cent). In the second part of the sedimentary column, the diagenetic modifications are mainly dominated by neomorphism, which is intense between 23 and $24 \mathrm{~m}, 26$ and $29 \mathrm{~m}, 35$ and $36 \mathrm{~m}$, and at approximately $39 \mathrm{~m}$. These levels are characterized by relatively low porosity values (minimum of 5 per cent). Finally, layers at the top of the sedimentary succession are associated with higher values of porosity (maximum of 30 per cent) related to dissolution and less intense neomorphism.
Along the whole sedimentary succession, the vertical variations in porosity are anticorrelated with $P$-wave velocity and density (Figs $6 \mathrm{~b}-\mathrm{d}$ ). In addition, thanks to the $P$-wave velocity and density measurements, the AI is computed (Fig. 6e), and a 1-D seismogram is processed (Fig. 6g). In our case, hard kicks (positive amplitude reflectors) are in red and display a downward increase in the acoustic impedance and positive reflectivity coefficients (SEG normal convention, e.g. reflector H9). Conversely, soft kicks (negative amplitude reflectors) are in blue and correspond to a downward decrease in the acoustic impedance and negative reflectivity coefficients (e.g. reflector S9). In the lower $5 \mathrm{~m}$ of the column, AI shows very high frequency variations without any metre-scale trend. This results in low-amplitude reflectors in the $500 \mathrm{~Hz}$ synthetic seismic data (S1, 


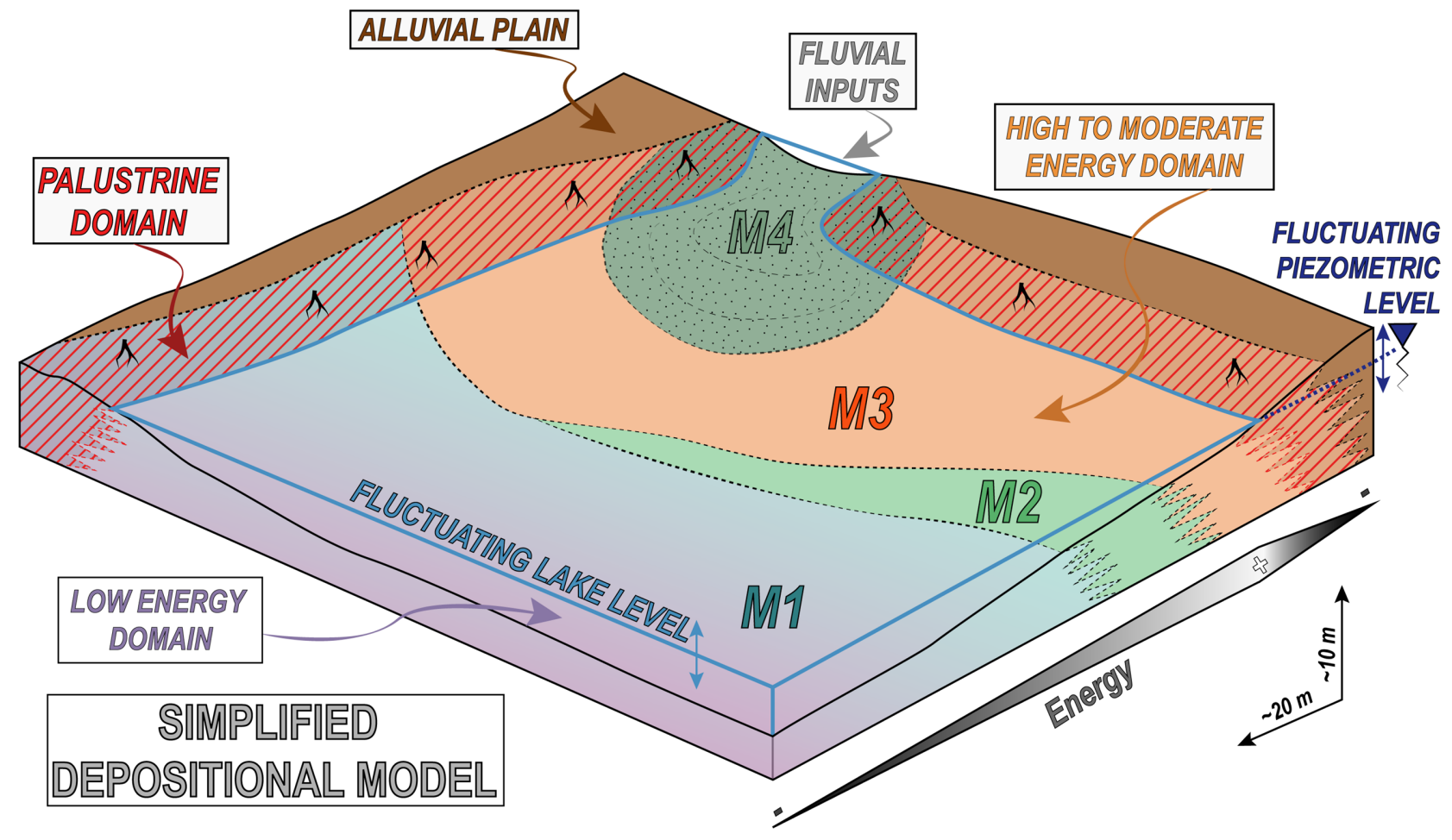

Figure 5. Simplified depositional model. All the microstructures described previously are displayed. Clotted mudstones and wackestones (M1) are grouped into a low energy domain. Peloidal and ooidal packstones (M2) and grainstones (M3) are associated with a marginal domain, possibly affected by hydrodynamism. Silty packstones (M4) are located close to a possible siliciclastic supply in the marginal domain. Root-rich microstructures are gathered within a palustrine domain that transitions laterally into alluvial plain deposits (marls).

$\mathrm{H} 1$ and S2). Conversely, in the remaining part of the succession, AI variations display lower frequency metre-scale variations that induce higher amplitude reflectors in the $500 \mathrm{~Hz}$ synthetic seismic data (H2 to S10).

Finally, combining field and microscopic observations, nine pedogenic levels have been recognized (red lines in Fig. 4 and dashed lines in Fig. 6). They correspond to exposure surfaces on which palaeosols developed (palustrine domain in Fig. 5). Seven of them are associated with intense neomorphism and correspond to high $P$-wave velocities (approximately $5000 \mathrm{~m} \mathrm{~s}^{-1}$ ) and low porosity values (approximately 10 per cent). These neomorphosed pedogenic levels are often associated with seismic reflectors.

\section{DISCUSSION: CONTROLLING FACTORS OF PHYSICAL PROPERTIES IN LACUSTRINE-PALUSTRINE CARBONATES}

\subsection{Sedimentary control of physical properties}

The behaviour of $P$-wave velocity versus porosity is compared with microstructures (Fig. 7) and mineralogy (Fig. 8). Based on the calcite content (Table 1), we define three mineralogical groups: group $1>99$ per cent, group 2 between 99 per cent and 97 per cent and group $3<97$ per cent. We use the Raymer-Hunt-Gardner equation (RHG; Raymer et al. 1980) to expose the classical trend of decreasing velocities with increasing porosity for a porous calcite framework saturated with air (eq. 1):

$V \mathrm{p}=(1-\Phi)^{2} * V \mathrm{p}_{\text {Calcite }}+\Phi * V \mathrm{p}_{\text {Fluid }}$, where $V p_{\text {Calcite }}=6400 \mathrm{~m} \mathrm{~s}^{-1}$ and $V p_{\text {Fluid(Air) }}=340 \mathrm{~m} \mathrm{~s}^{-1}$. RHG is an improvement of the Wyllie Time Average equation (WTA; Wyllie et al. 1956) that allows for a better characterization of the elastic behaviour of consolidated rocks. Indeed, as shown by Mavko et al. (2009), in the case of consolidated and cemented sandstones, WTA underestimates the $P$-wave velocities for a given porosity, while RHG tends to fit these data. The assumptions of RHG imply that: (i) the characterized rocks are isotropic and monomineralic; (ii) they do not contain any compliant crack-like pores or stiff pores; and (iii) they are well cemented/consolidated. Using the RHG equation enables us to compare our data set to an empirical commonly used evolution of $P$-wave velocity versus porosity.

The mudstones and wackestones (M1) show $P$-wave values centred on $4500 \mathrm{~m} \mathrm{~s}^{-1}$ and porosity values mainly between 10 per cent and 20 per cent (Fig. 7). Most of this data set follows the RHG equation. This observation is in line with the microstructure, which presents a mostly equant porosity (isotropic mixture of microporous matrix and peloids with few moulds and no microcracks; Fig. 2) and a pure calcite mineralogy (Table 1 and Fig. 8). Nevertheless, a few outliers present $P$-wave velocities that are approximately $1000 \mathrm{~m} \mathrm{~s}^{-1}$ lower than the RHG predictions. These anomalous data can be explained by the influence of siliciclastic content (Fig. 8) that may decrease the $P$-wave velocity, as previously shown by numerous authors (e.g. Anselmetti et al, 1997; Kenter et al. 1997; Regnet et al. 2019). In addition, the presence of palaeosols also explains some anomalous data (see section 4.2.1).

The data set obtained for the peloidal packstones (M2) also fits with the RHG equation (Fig. 7). The ooidal and peloidal grainstones (M3) exhibit the highest range of $P$-wave velocities and porosity (Fig. 7). The data for this facies are in agreement with the RHG trend for porosity values lower than 25 per cent. However, for 


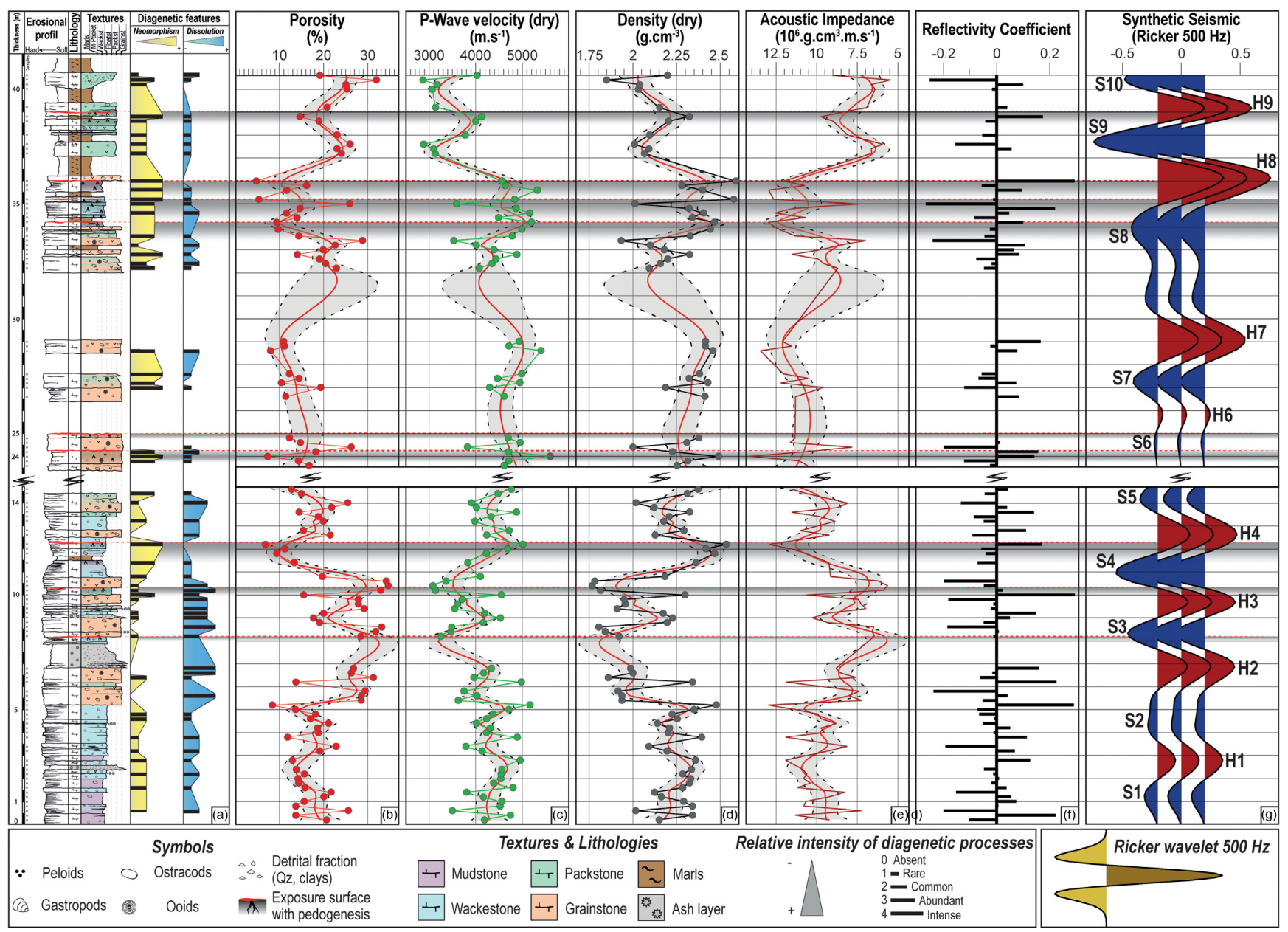

Figure 6. Geological and physical properties of the studied section. On the sedimentary log, the colours represent the different primary microstructures (a). The $\log$ is compared to the relative intensity of diagenetic features (rare to intense) and physical properties acquired on plugs. Pedogenic horizons are highlighted with thick shaded areas capped by dashed red lines (exposure surfaces). Smooth curves with 95 per cent confidence intervals are indicated for porosity (b), $P$-wave velocity (c), density (d) and acoustic impedance (e). The reflectivity coefficient is also indicated (f). A convolution with a Ricker wavelet of $500 \mathrm{~Hz}$ is applied to the reflectivity coefficient to compute a synthetic seismic trace (f), highlighting the succession of hard kick in red (H) and soft kick in blue (S).

porosity values higher than 25 per cent, the data set presents values of $P$-wave velocities higher than those predicted by RHG (approximately $1000 \mathrm{~m} \mathrm{~s}^{-1}$ higher). The mineralogical characterization and petrographic work show that most of these samples present a pure calcite mineralogy (Table 1 and Fig. 8) and contain well-defined and non-touching spherical pores (moulds), which probably increase the bulk incompressibility and thus the $P$-wave velocities, as shown by many authors (Anselmetti \& Eberli 1993; Eberli et al. 2003; Fortin et al. 2007; Weger et al. 2009; Fig. 2b-4).

Finally, most of the silty packstone (M4) displays low $P$-wave velocity values (lower than $4000 \mathrm{~m} \mathrm{~s}^{-1}$ ) with high porosity values (higher than 20 per cent). Most of this data set is less than the RHG values (approximately $1000 \mathrm{~m} \mathrm{~s}^{-1}$ less). As previously shown, their siliciclastic content ( $>5$ per cent; Table 1) induces a decrease in the bulk incompressibility and controls the $P$-wave velocity values (Fig. 8).

Curves of constant impedance are also shown in Figs 7 and 8. They do not allow the distinction of primary microstructures, except for the silty packstones, which present the lowest AI, always below $10 \times 10^{6} \mathrm{~g} \mathrm{~cm}^{3} \mathrm{~m} \mathrm{~s}^{-1}$. Indeed, for the other primary microstructures, the $\mathrm{AI}$ is between $6 \times 10^{6}$ and $14 \times 10^{6} \mathrm{~g} \mathrm{~cm}^{3} \mathrm{~m} \mathrm{~s}^{-1}$ (Fig. 7).

\subsection{Impact of diagenesis on microstructures and physical properties}

\subsubsection{Pedogenic versus non-pedogenic mudstones and wackestones}

Fig. 9 shows the $P$-wave velocity versus porosity for pure calcite mudstones and wackestones (M1; Fig. 2a-1). All the non-pedogenic mudstones and wackestones are reflected by the physical properties of the first $5 \mathrm{~m}$ of the $\log$ (Fig. 6); these rocks contain microporosity between subrounded micrite crystals (Fig. 2c-2-3). Conversely, for samples associated with root traces $(12.2,34.2,35.2$ and $36 \mathrm{~m}$ in Fig. 6), an increase in neomorphism leads to the formation of fused micrite that decreases the porosity (Fig. 2c-5-6), thus increasing the $P$-wave velocity. Indeed, the boxplots of Fig. 9 aim to clearly individualize these two microstructures: (1) most of the nonpedogenic mudstones/wackestones show $P$-wave velocities lower than $4600 \mathrm{~m} \mathrm{~s}^{-1}$ and porosities higher than 14 per cent, whereas (2) most of the pedogenic mudstones/wackestones display $P$-wave velocities higher than $4600 \mathrm{~m} \mathrm{~s}^{-1}$ and porosities lower than 15 per cent. These two different behaviours of elasticity are linked with the intensity of neomorphism, which implies a change in microstructures (from subrounded to fused micrite, Figs 2c and 9), thus governing 


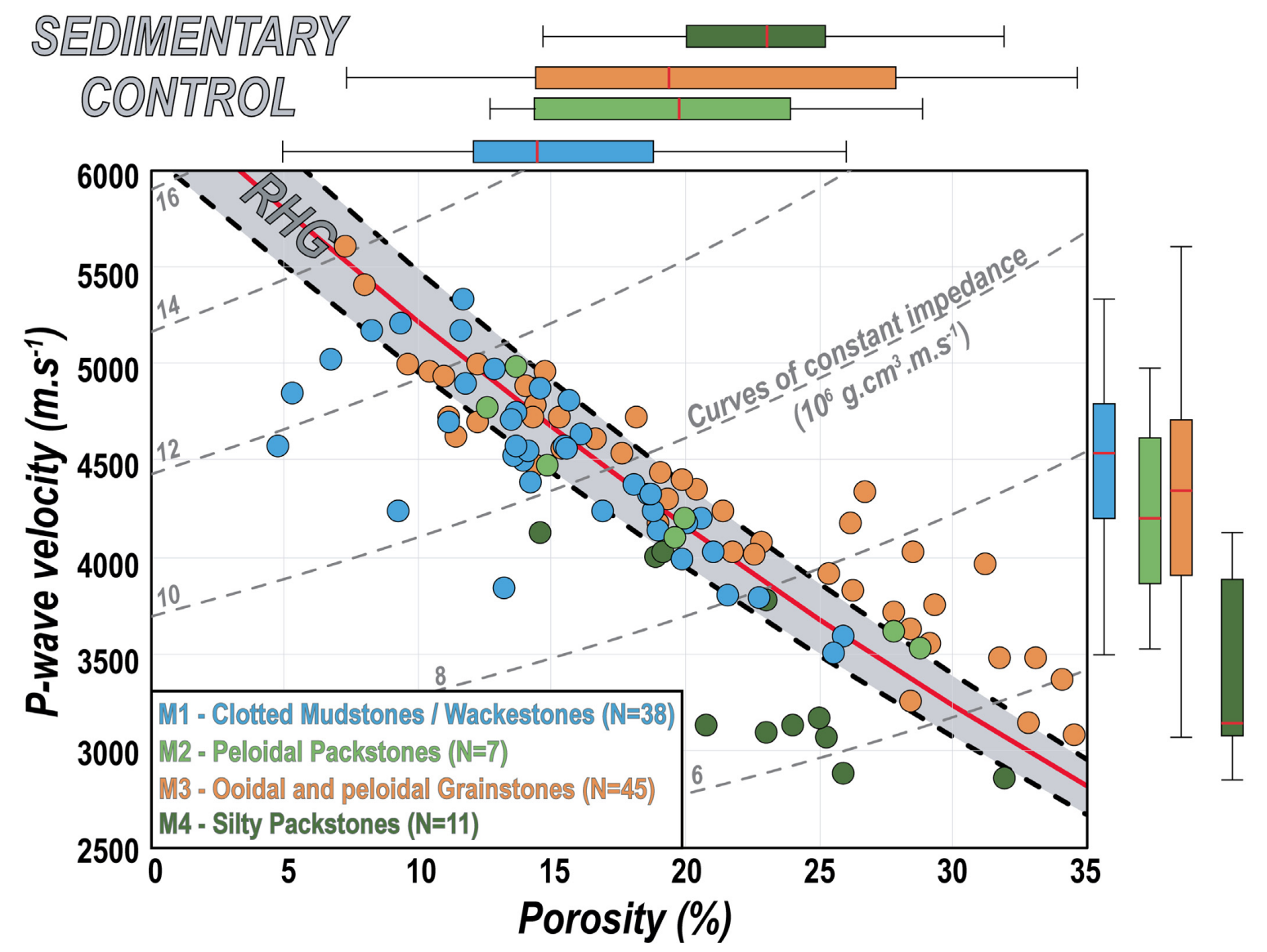

Figure 7. Sedimentary control on $P$-wave velocity and porosity. The Raymer-Hunt-Gardner equation (RHG) is indicated for a pure calcite framework with 5 per cent variation (grey area). Boxplots showing the distributions of $P$-wave velocity and porosity are indicated and categorized by primary microstructures.

the evolution of porosity and $P$-wave velocity. It should be noted that the lowest porosity samples $(\Phi<7$ per cent) of the pedogenic mudstones/wackestones data set present lower $P$-wave velocities than expected based on RHG (Fig. 9). Even if no crack-like pores were observed during petrographic description of these samples, the occurrence of compliant microcracks might explain these outliers. Indeed, pedogenesis can be associated with cracking processes related to repeated exposures and root activity. Nevertheless, even if these outliers show lower values of $P$-wave velocity, their AI values remain high (approximately $12 \times 10^{6} \mathrm{~g} \mathrm{~cm}^{3} \mathrm{~m} \mathrm{~s}^{-1}$ ).

The curves of constant impedance of Fig. 9 aim to further divide this data set. Indeed, the pedogenic mudstones-wackestones exhibit AI values higher than $10 \times 10^{6} \mathrm{~g} \mathrm{~cm}^{3} \mathrm{~m} \mathrm{~s}^{-1}$, while most of the nonpedogenic mudstones-wackestones present AI values lower than 10 $\times 10^{6} \mathrm{~g} \mathrm{~cm}^{3} \mathrm{~m} \mathrm{~s}^{-1}$. As a consequence, the vertical stacking of neomorphosed and non-neomorphosed mudstones-wackestones might induce vertical contrasts in AI, thus creating seismic reflectors.

\subsubsection{Neomorphism versus dissolution processes in grainstones}

Fig. 10 shows the $P$-wave velocity versus porosity values of peloidal and ooidal grainstone samples (M3; Fig. 2a-3) that record different diagenetic histories (neomorphism or dissolution; Fig. 2b-3-4). These samples exhibit $P$-wave velocities ranging between 3000 and $5600 \mathrm{~m} \mathrm{~s}^{-1}$ and porosity values varying between 7 and 35 per cent. Neomorphism-dominated samples and dissolution-dominated samples are distinguished to show the impact of diagenesis on the physical properties. Indeed, Fig. 10 shows two different end-members:
(1) one (yellow colour) is associated with high neomorphism, low porosity values (between 7 and 23 per cent) and high velocities (between 5600 and $4000 \mathrm{~m} \mathrm{~s}^{-1}$ ); (2) the other one (blue colour) is related to high dissolution, higher porosity values (between 18 and 35 per cent) and lower velocities (between 4500 and $3000 \mathrm{~m} \mathrm{~s}^{-1}$ ). Samples showing a non-negligible amount of both neomorphism and dissolution are located between these two end-members. This data set clearly highlights the impact of dissolution on microstructures and physical properties. Indeed, in the case of neomorphismdominated samples, the absence of dissolution implies low porosity values and thus high velocities. In contrast, in the case of increasing dissolution, the increasing porosity implies a decrease in the velocity.

Curves of constant impedance are also indicated in Fig. 10. They show that the AI for grainstones varies between $6 \times 10^{6}$ and $14 \times 10^{6} \mathrm{~g} \mathrm{~cm}^{3} \mathrm{~m} \mathrm{~s}^{-1}$. A transition between neomorphismdominated and dissolution-dominated samples is identified at approximately $10 \times 10^{6} \mathrm{~g} \mathrm{~cm}^{3} \mathrm{~m} \mathrm{~s}^{-1}$, which demonstrates that diagenetic evolution has a direct impact on acoustic impedance. The stronger the neomorphism is, the higher the acoustic impedance is. Moreover, the intensity of neomorphism controls the subsequent evolution of the microstructure. Indeed, the weaker the neomorphism is, the more grainstones are subject to subsequent dissolution and are associated with lower acoustic impedance. The vertical distribution of these diagenetic phases may therefore be at the origin of AI contrasts that produce seismic reflectors. 


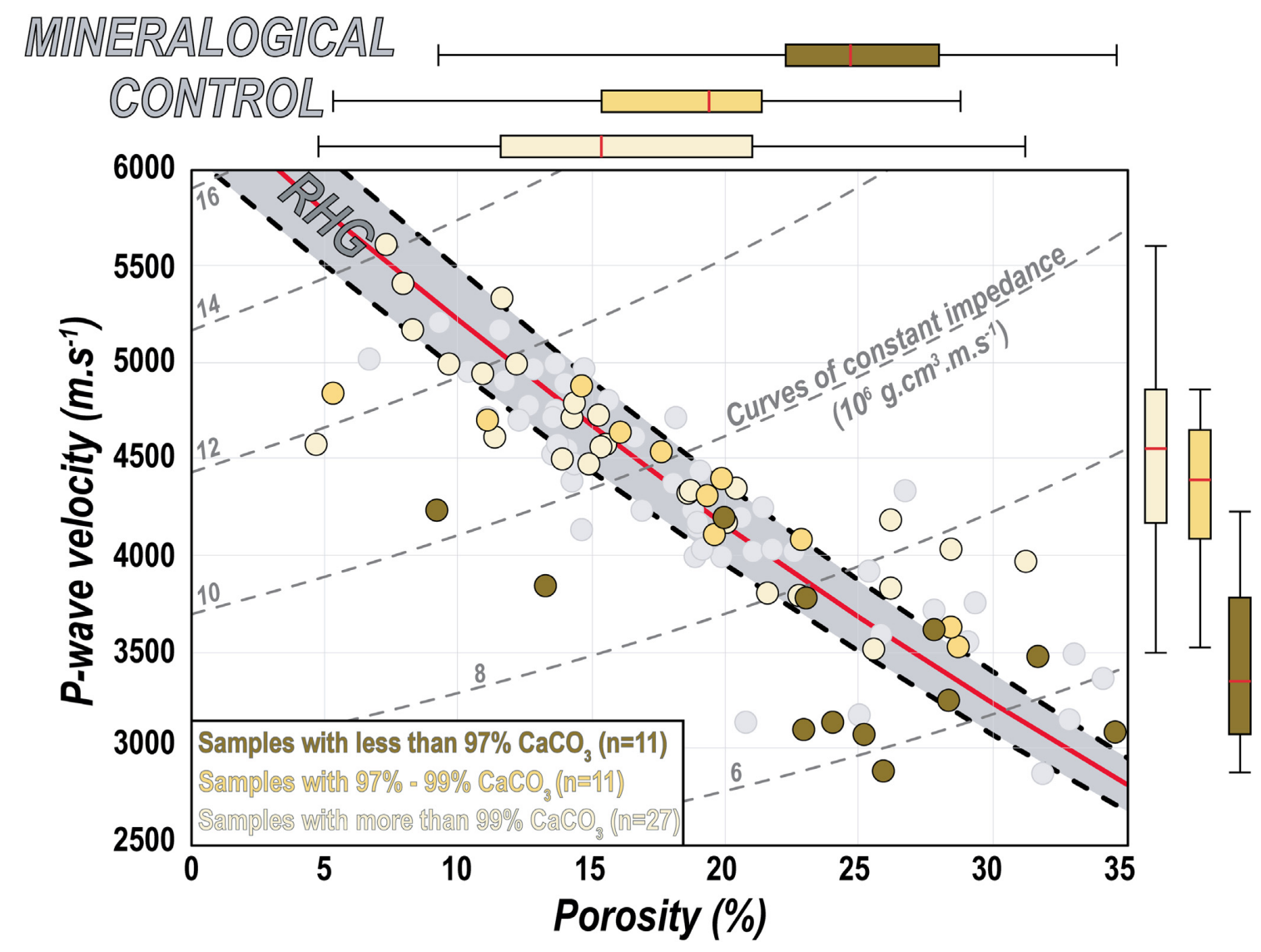

Figure 8. Mineralogical control of $P$-wave velocity and porosity. The grey dots correspond to non-measured mineralogy. The Raymer-Hunt-Gardner equation (RHG) is indicated for a pure calcite framework with 5 per cent variation (grey area). The data set is divided into three mineralogical groups. Boxplots showing the distributions of $P$-wave velocity and porosity are indicated and classified with respect to the mineralogical groups.

\subsection{Geological significance of seismic reflectors in lacustrine carbonates}

Based on our results, a conceptual model explaining the geological controlling factors of seismic reflectors in lacustrine-palustrine carbonates is proposed (Fig. 11). Such shallow environments are subject to important lake and piezometric level fluctuations (Fig. 5) that imply spatial contrasts of primary and secondary microstructures, partly related to repeated exposures associated with pedogenesis. Our model introduces the combined controls of primary microstructures and diagenetic overprinting on the porosity evolution and the associated seismic reflectors (Fig. 11). It is based on three examples taken from Fig. 6 that present different geological controlling factors of seismic reflectors:

(1)The first example highlights diagenetic contrasts implying the creation of two seismic reflectors on the same primary microstructure (Fig. 11a): (i) A hard kick corresponding to an exposure surface (H9) links to a sharp boundary between overlying nonneomorphosed silty packstones (keeping their primary porosity, $\Phi_{0}$ ) and underlying neomorphosed silty packstones (showing lower porosity because of neomorphism, $\partial \Phi-$ ); and (ii) a soft kick corresponding to a higher porosity level (S9) due to a downward decrease of neomorphism (thus a downward increase in porosity) until a non-neomorphosed silty packstone level that preserves its primary porosity $\left(\Phi_{0}\right)$;

(2)The second case (Fig. 11b) highlights (i) another exposure surface with similar underlying and overlying primary microstructure but with a diagenetic contrast that creates a hard kick (H4), and this surface corresponds to a sharp boundary between nonneomorphosed wackestones (preserving their primary porosity, $\Phi_{0}$ ) and neomorphosed wackestones (displaying lower porosity caused by neomorphism, $\partial \Phi-$ ); and (ii) a sedimentary contrast overprinted by diagenesis displaying a soft kick (S4), which corresponds to a boundary between partly neomorphosed wackestones $(\partial \Phi-)$ and grainstones affected by mouldic dissolution $(\partial \Phi+)$;

(3)Finally, the third example (Fig. 11c) shows the impact of stacking exposures on seismic reflectors, presenting (i) a sedimentary contrast overprinted by diagenesis that creates a hard kick (H8), corresponding to a boundary between non-neomorphosed silty packstones (preserving their primary porosity, $\Phi_{0}$ ) and neomorphosed wackestones (with lower porosity caused by diagenesis, $\partial \Phi-$ ), again related to an exposure surface; and (ii) an attenuated soft kick (S8) associated with the occurrence of another exposure surface that implies low porosities as above $(\partial \Phi-)$, thus preventing a geological vertical contrast even if grainstones partly affected by mouldic dissolution are located below $(\partial \Phi+)$.

These three different cases outline the impact of the vertical distribution of primary microstructures, that is, the sedimentary contrasts between mud-supported (mudstones and wackestones) and grain-supported microstructures (packstones and grainstones) on the generation of seismic reflectors. These sedimentary contrasts may be overprinted by diagenetic processes, forming physical contrasts between non-diagenetically modified microstructures $\left(\Phi_{0}\right)$, 


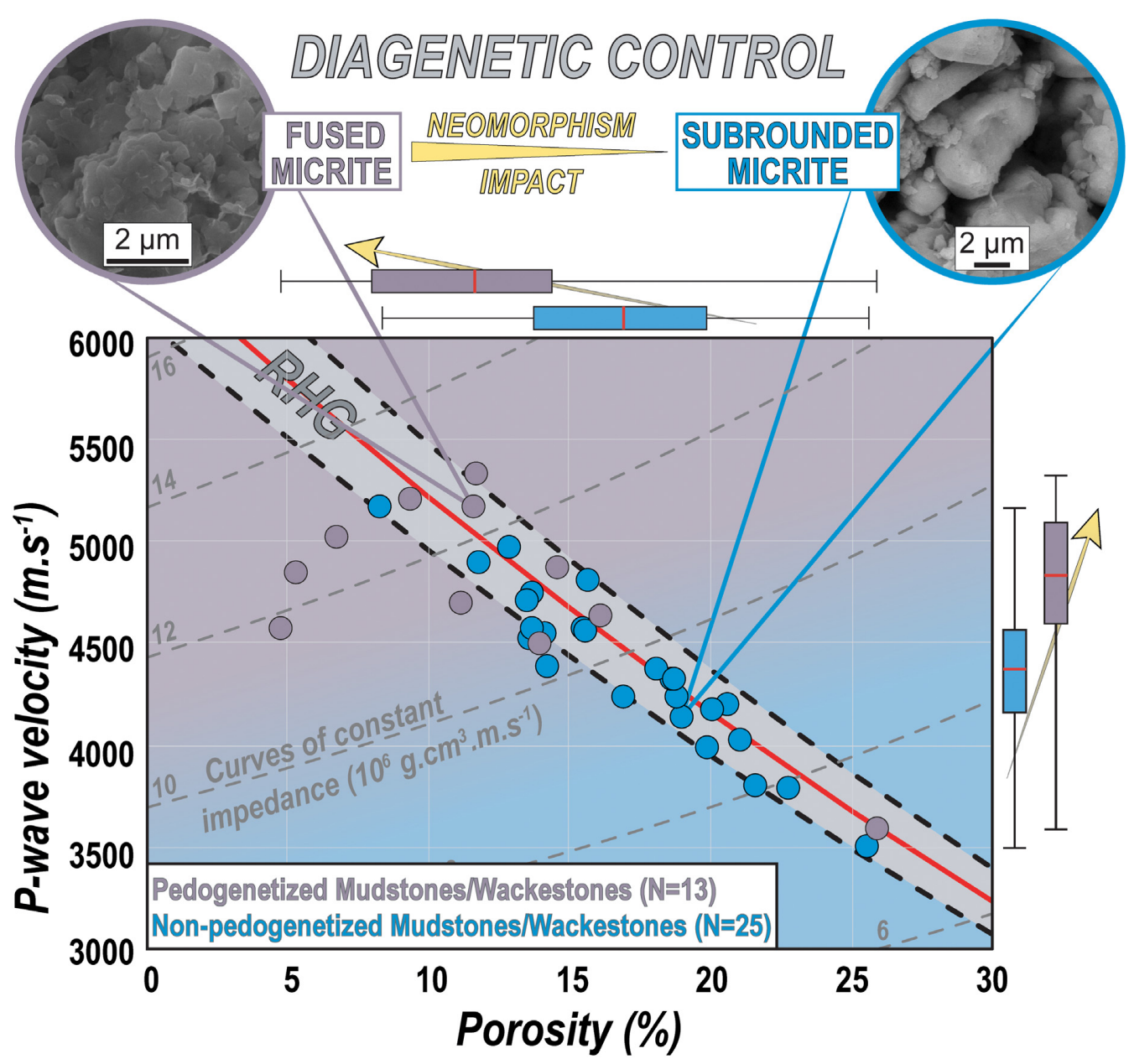

Figure 9. $P$-wave velocity versus porosity, showing the influence of neomorphism for pure mudstones/wackestones (M1). Pedogenic and non-pedogenic mudstones/wackestones are differentiated with colours (purple and blue, respectively). The Raymer-Hunt-Gardner equation (RHG) is indicated for a pure calcite framework with 5 per cent variation (grey area). Boxplots showing the distributions of $P$-wave velocity and porosity are also indicated. Two SEM views show the impact of neomorphism on the micrite structure and the physical properties.

microstructures affected by neomorphism $(\partial \Phi-)$ and microstructures affected by dissolution $(\partial \Phi+)$, leading to seismic reflectors (Figs 6 and 11).

From a geological point of view, we suggest that palaeopiezometric level fluctuations control the early diagenesis described above. Indeed, between the exposure surface and piezometric level (see Fig. 5), the non-saturated zone (vadose zone) is associated with the episodic percolation of meteoric water, which can favour neomorphism processes (Buchbinder \& Friedman 1980). This first diagenetic phase could induce a huge decrease in porosity (Steinen 1978), as observed here (Figs 9 and 10). It follows the synsedimentary micritization of the grains (Figs 3a and b-1) and implies mineralogical stabilization. Conversely, early dissolution processes could also occur, depending on the primary mineralogy of the sediments and the fluid chemistry. As an example, high-magnesian calcite or aragonite (e.g. the unstable mineralogy of ooliths) may be dissolved by fluids that are under-saturated with respect to this mineralogy (Buchbinder \& Friedman 1980). However, grains affected by early micritization and neomorphism are not dissolved, mainly due to their stable mineralogy (low-magnesian calcite). The early mouldic dissolution observed in this study may occur below the piezometric level in the phreatic zone (e.g. caused by a mixing between meteoric and lacustrine waters) only if the grains are not previously modified by micritization and neomorphism. In all cases, the relationships between sedimentary, diagenetic and physical contrasts of lacustrine-palustrine carbonates are obvious.

As a rule, the primary microstructure and mineralogy of the sediments (stable versus unstable) can impact its diagenetic evolution related to the fluctuations of the lake level (Fig. 5), thus controlling physical property contrasts and the generation of seismic reflectors (Figs 6 and 11). Exposure surfaces manifest as a hard kick if neomorphism processes are well developed below it, that is, exposure surfaces imply a downward increase in the acoustic impedance (related to a downward decrease in porosity) and thus a positive reflectivity coefficient (Fig. 6; H4, H8 and H9). In contrast, the absence of early neomorphism (related to the preservation of primary microstructure or with an enhanced porosity caused by dissolution) induces the formation of a soft kick, that is, diagenetic and sedimentary contrasts overprinted by diagenesis imply a downward decrease in the acoustic impedance (related to a downward increase in porosity) and thus a negative reflectivity coefficient (Fig. 6; S4, S5, S9 and S10). Furthermore, as stated by Bohacs et al. (2000), climate forcing and tectonic setting are the first-order controlling factors of lake sedimentation and strongly govern the hydrology of continental basins (e.g. water chemistry, rainfall and evaporation). As a consequence, the combination of structural setting (e.g. uplift 


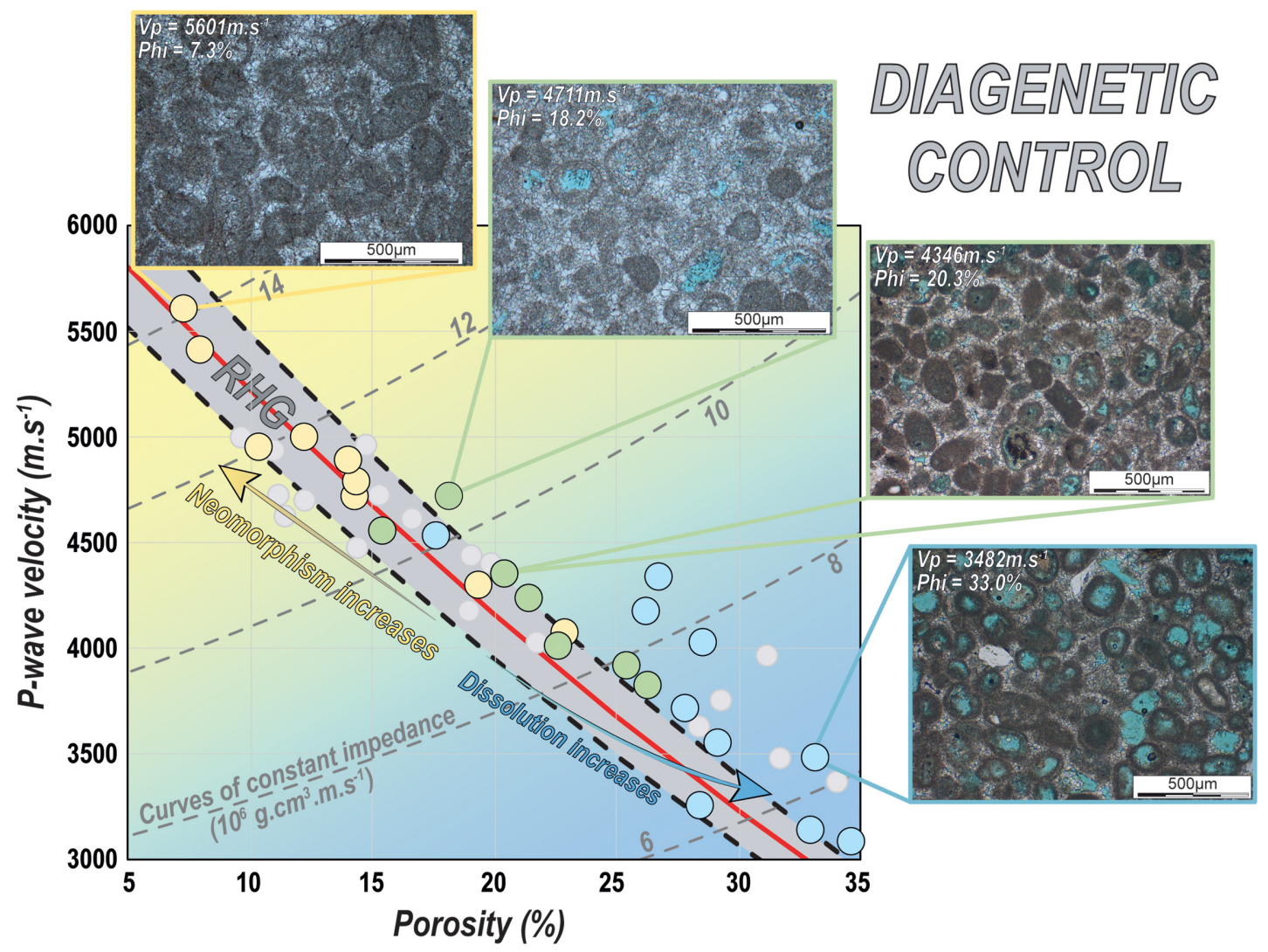

Figure 10. $P$-wave velocity versus porosity, showing the influence of diagenesis for grainstones (M3). Neomorphism-dominated samples are in yellow, and dissolution-dominated samples are in blue. Samples showing both significant evidence of neomorphism and dissolution are highlighted in green. Four photomicrographs display examples of the same primary microstructures with different intensities of diagenetic modifications. Curves of constant impedance are indicated in grey. The Raymer-Hunt-Gardner equation (RHG) is indicated for a pure calcite framework with 5 per cent variation (grey area).

proposed by Ring et al. 1999) and climate influence (e.g. increasing aridity proposed by Owen et al. 2011) are suggested as potential indirect controlling factors of seismic reflectors for lacustrine and palustrine carbonates.

\section{CONCLUSION}

In this paper, we compare the microstructures and physical properties of lacustrine-palustrine carbonates in a sedimentary column. Based on petrographic work, we define different primary (i.e. sedimentary) and secondary (i.e. diagenetic) microstructures. $P$-wave velocity and porosity data are compared to the Raymer-HuntGardner equation, which displays the typical decreasing velocity for increasing porosity in the case of consolidated and cemented pure calcite rocks, and the results show the following:

(1)Most of the data set fits with RHG prediction. The pure mudstone/wackestone matched well with RHG. Silty packstones exhibit lower velocities than RHG, mostly due to their mineralogical content, as evidenced by XRD analyses ( $>5$ per cent of siliciclastic minerals). In contrast, some ooidal and peloidal grainstones present higher velocities than RHG, showing the control of stiff pores (mouldic porosity). Nevertheless, the identification of only primary microstructures does not allow them to be differentiated on a velocity-porosity plot because of their large variability in porosity (between 5 per cent and 35 per cent) and $P$-wave velocity (between 5600 and $2800 \mathrm{~m} \mathrm{~s}^{-1}$ ).
(2)Considering the microstructure in the light of diagenesis aims to underline two important processes that impact the physical properties: neomorphism and dissolution. Neomorphism allows the recrystallization of muddy microstructures (development of fused micrite) and micritized ooids and peloids of grain-supported microstructures (packstones and grainstones) that produce a decrease in porosity, thus increasing the $P$-wave velocity. Conversely, mouldic dissolution increases the porosity, thus decreasing the $P$ wave velocity (mainly observed in the peloidal and ooidal grainstones). These two diagenetic processes control the acoustic properties of lacustrine and palustrine carbonates and can be clearly differentiated on the velocity-porosity plots for each primary microstructure.

Using our data set, we compute a 1-D seismogram. For convolution, we apply a Ricker wavelet of $500 \mathrm{~Hz}$ using the SEG convention, giving us a metre-scale resolution comparable to that of high-resolution crosswell seismic. The identified seismic reflectors correspond to contrasts in acoustic impedance with geological significance:

(1)Hard kicks correspond to downward increases in acoustic impedance and thus decreases in porosity. They are often associated with contrasts between non-modified primary microstructures and highly neomorphosed microstructures. They correspond to exposure surfaces related to palaeosols.

(2)Conversely, soft kicks correspond to downward decreases in acoustic impedance and thus increases in porosity. They are associated with diagenetic contrasts (e.g. neomorphosed wackestones 


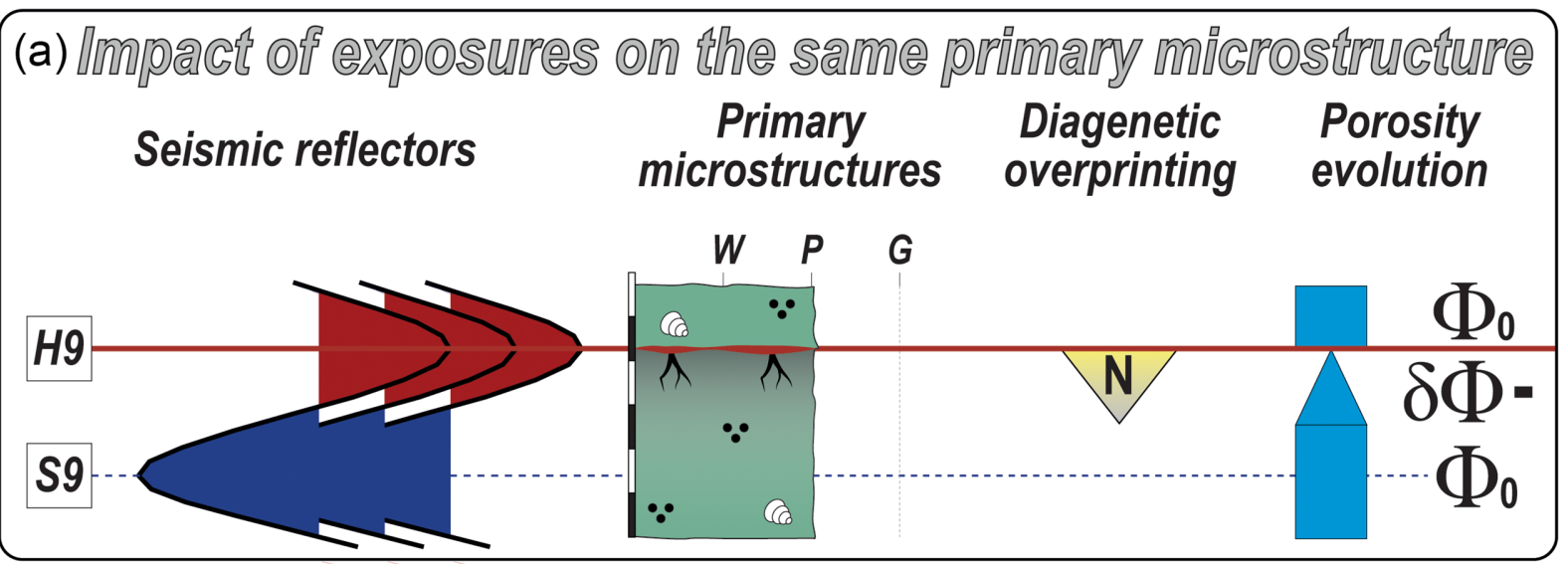

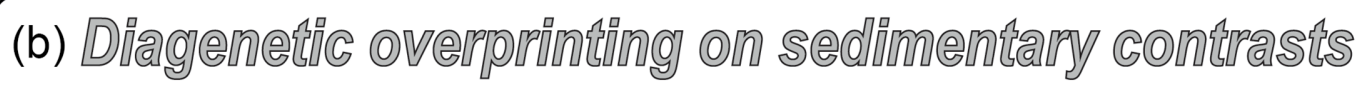

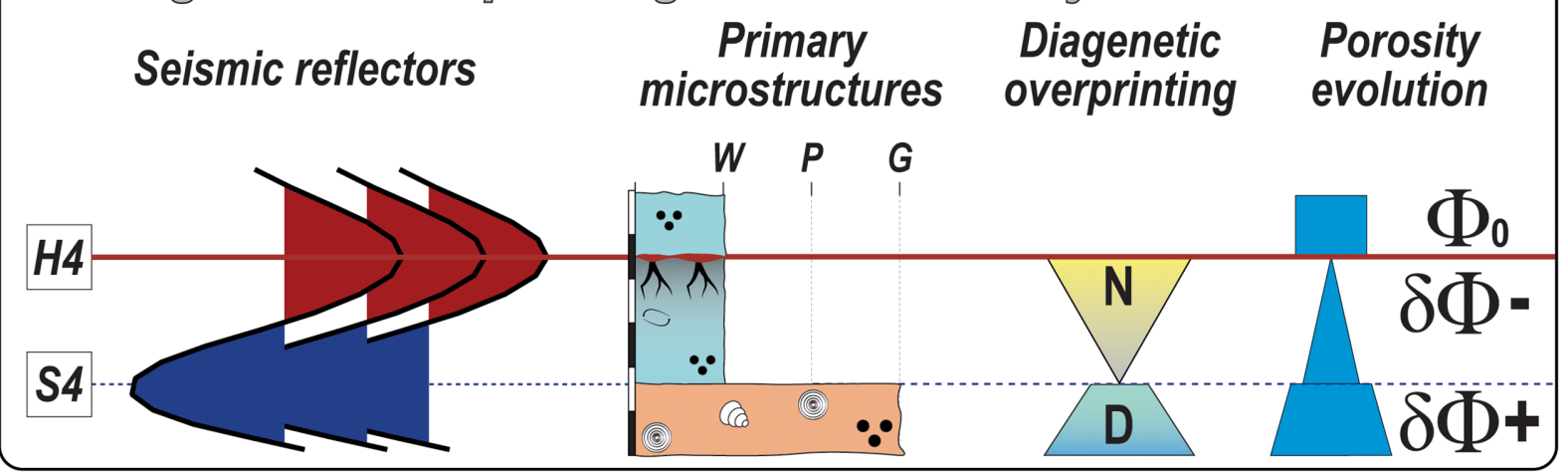

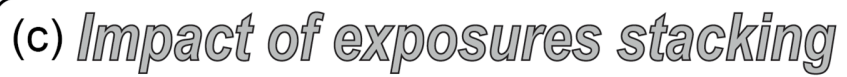

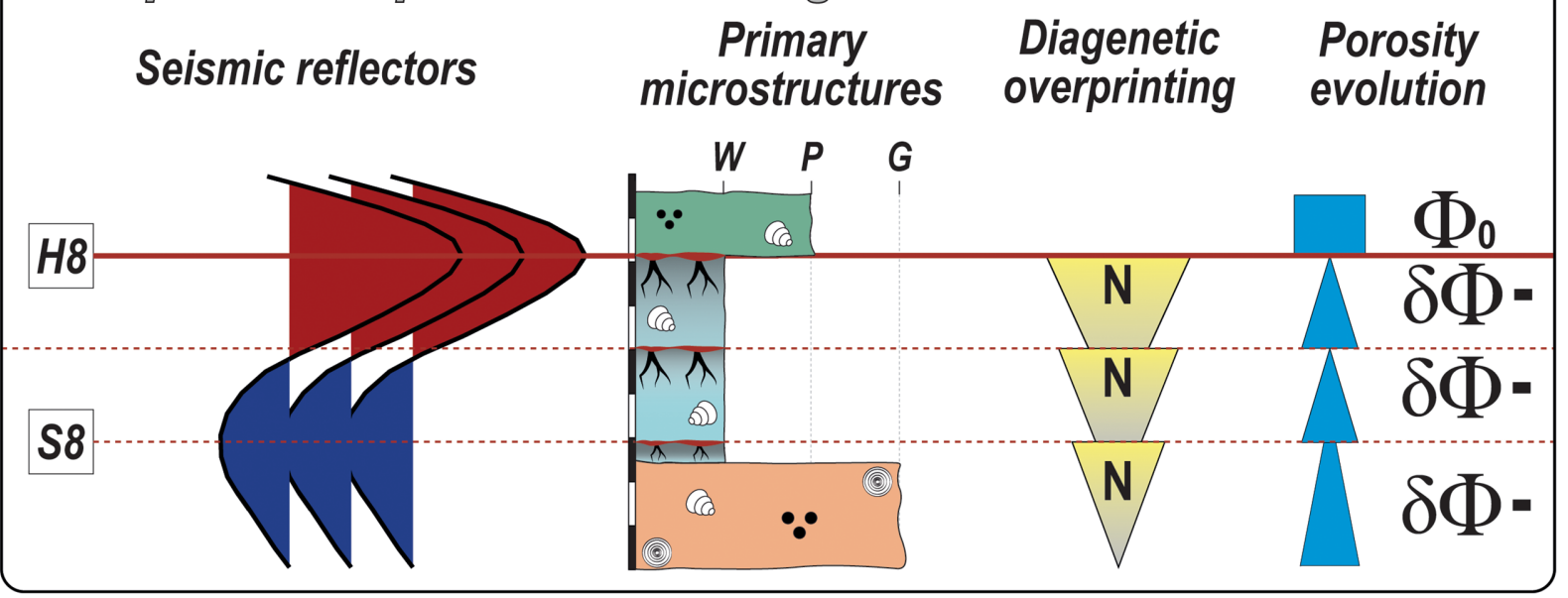

Figure 11. Geological significance of high-resolution seismic reflectors. Primary microstructures and intensities of diagenetic processes are displayed and associated with the porosity evolution $\left(\partial \Phi-, \Phi_{0}\right.$ and $\left.\partial \Phi+\right)$. (a) Impact of the neomorphosed interval below the exposure surface on seismic reflectors displayed on the same primary microstructure. (b) Seismic reflectors controlled by a combination of primary microstructure contrasts overprinted by diagenetic contrasts. (c) Influence of exposure surface stacking on seismic reflectors.

versus non-modified wackestones) and sedimentary contrasts that can be overprinted by diagenesis (e.g. neomorphosed wackestones versus mould-rich grainstones).

It must be noted that the primary microstructures and their primary mineralogy (e.g. low-magnesian calcite versus highmagnesian calcite or aragonite) control the subsequent diagenetic expression. Indeed, mud-supported carbonates (e.g. mudstones and wackestones) may be more subject to neomorphism than grainsupported carbonates (e.g. packstones and grainstones). Conversely, grain-supported carbonates are more prone to dissolution than the mud-supported carbonates if they are not previously modified by early micritization and neomorphism. Indeed, these two early diagenetic processes imply a mineralogical stabilization of the grains that prevents subsequent dissolution. Consequently, high-resolution seismic reflectors of lacustrine-palustrine carbonates depend on the 
spatial contrasts of primary microstructures overprinted by early diagenesis that may be linked with lake palaeohydrology.

\section{ACKNOWLEDGEMENTS}

This work is supported by IFP Energies Nouvelles (grant $\mathrm{XFP} 32 / 001)$. It is a part of the $\mathrm{PhD}$ project of the first author, at IFP Energies Nouvelles and Laboratoire de Géologie of Ecole normale supérieure. The data set used in this paper is available from the corresponding author (CB). We thank Herman Ravelojaona (IFPEN) for the preparation of the thin sections and Damien Deldicque (ENS) for the SEM observations. We also thank Hannes Claes, two anonymous reviewers, Editor-in-Chief Joerg Renner and the associate editors Alexis Maineult and Lapo Boschi for their constructive comments which helped to significantly improve the manuscript.

\section{REFERENCES}

Al-Chalabi, M., 2014. Principles of Seismic Velocities and Time-to-Depth Conversion, p. 491, EAGE Publications.

Alonso-Zarza, A.M., 2003. Palaeoenvironmental significance of palustrine carbonates and calcretes in the geological record, Earth. Sci. Rev., 60, 261-298.

Alonso-Zarza, A.M. \& Tanner, L.H., 2010a. Carbonates in continental settings: Facies, environments and processes, in Developments in Sedimentology, vol. 61, p. 400.

Alonso-Zarza, A.M. \& Tanner, L.H., 2010b. Carbonates in continental settings: Geochemistry, diagenesis and applications, Developments in Sedimentology, vol. 62, p. 336, Elsevier.

Anselmetti, F.S. \& Eberli, G.P., 1993. Controls on Sonic Velocity in Carbonates, in: Experimental Techniques in Mineral: The Shreiber Volume, pp. 287-323, eds. Liebermann, R.C. \& Sondergeld, C.H., Birkhäuser, doi:10.1007/BF00998333.

Anselmetti, F.S., Von Salk, G.A., Cunningham, K.J. \& Eberli, G.P., 1997. Acoustic properties of Neogene carbonates and siliciclastics from the subsurface of the Florida Keys: implications for seismic reflectivity, Mar. Geol., 144, 9-31.

Avseth, P., Dvorkin, J., Mavko, G. \& Rykkje, J., 2000. Rock physics diagnostic of North Sea sands: Link between microstructure and seismic properties, Geophys. Res. Lett., 27(17), 2761-2764.

Bohacs, K.M., Carroll, A.R., Neal, J.E. \& Mankiewicz, P.J., 2000. Lakebasin type, source potential, and hydrocarbon character: an integratedsequence-stratigraphic-geochemical framework, in Lake basins through space and time, vol. 46, pp. 3-34, eds. Gierlowski-Kordesch, E.H. \& Kelts, K.R., AAPG Studies in Geology.

Brigaud, B., Vincent, B., Durlet, C., Deconinck, J.-F., Blanc, P. \& Trouiller, A., 2010. Acoustic Properties of Ancient Shallow-Marine Carbonates. Effects of Depositional Environments and Diagenetic Processes (Middle Jurassic, Paris Basin, France), J. Sed. Res., 80, 791-807.

Buchbinder, L.G. \& Friedman, G.M., 1980. Vadose, phreatic, and marine diagenesis of Pleistocene-Holocene carbonates in a borehole; Mediterranean coast of Israel, J. Sed. Petro., 50(2), 395-407.

Choquette, P.W. \& Pray, L.C., 1970. Geologic Nomenclature and Classification of Porosity in Sedimentary Carbonates, AAPG Bull., 54, 207-250.

Davies, R.J. \& Cartwright, J.A., 2007. Kilometer-scale chemical reaction boundary patterns and deformation in sedimentary rocks, Earth Planet. Sci. Let., 262, 125-137.

Dunham, R.J., 1962. Classification of Carbonate Rocks According to Depositional Textures, in Classification of Carbonate Rocks, pp. 108-121, ed. Ham, W.E., AAPG, Tulsa.

Eberli, G.P., Baechle, G.T., Anselmetti, F.S. \& Incze, M.L., 2003. Factors controlling elastic properties in carbonate sediments and rocks, Leading Edge, 22, 654-660.

Folk, R.L., 1965. Some aspects of recrystallization in ancient limestones, in Dolomitization and Limestone Diagenesis, vol. 13, pp. 14-48, eds. Pray, L.C. \& Murray, R.S., SEPM Special Publication.
Fortin, J., Schubnel, A. \& Gueguen, Y., 2007. Effects of pore collapse and grain crushing on ultrasonic velocities and $\mathrm{Vp} / \mathrm{Vs}$, J. geophys. Res., 112(B8), 16. doi: 10.1029/2005JB004005.

Fournier, F. \& Borgomano, J., 2007. Geological significance of seismic reflections and imaging of the reservoir architecture in the Malampaya gas field (Philippines), AAPG Bull., 91(2), 235-258.

Fournier, F. et al., 2018. The equivalent pore aspect ratio as a tool for pore type prediction in carbonate reservoirs, AAPG Bull., 102(7), 1343-1377.

Guerin, G. \& Goldberg, D., 1996. Acoustic and elastic properties of calcareous sediments across a siliceous diagenetic front on the eastern U.S. continental slope, Geophys. Res. Lett., 23(19), 2697-2700.

Hardage, B.A., Carr, D.L., Lancaster, D.E., Simmons, J.L., Jr., Elphick, R.Y., Pendleton, V.M. \& Johns, R.A., 1996. 3-D seismic evidence of the effects of carbonate karst collapse on overlying clastic stratigraphy and reservoir compartmentalization, Geophysics, 61, 1336-1350.

Harris, J.M., Nolen-Hoeksema, R.C., Langan, R.T., Van Schaack, M., Lazaratos, S.K. \& Rector, J.W., III, 1995. High-resolution crosswell imaging of a Texas carbonate reservoir: Part I-Project summary and interpretation, Geophysics, 60, 667-681.

Ioakim, C. \& Koufos, G.D., 2009. The Late Miocene Mammal Faunas of the Mytilinii Basin, Samos Island, Greece: New Collection. 3. Palynology, Beiträge zur Paläontologie, 27-35.

Jafarian, E., De Jong, K., Kleipool, L.M., Scheibner, C., Blomeier, D.P.G. \& Reijmer, J.J.G., 2018. Synthetic seismic model of a Permian biosiliceous carbonate - carbonate depositional system (Spitsbergen, Svalbard Archipelago), Mar. and Petrol. Geol., 92, 78-93.

Jarrard, R.D., Niessen, F., Brink, J.D. \& Bücker, C., 2000. Effects of cementation on velocities of siliciclastic sediments, Geophys. Res. Lett., 27(5), 593-596.

Kenter, J., Podladchikov, F., Reinders, M., Van der Gaast, S., Fouke, B. \& Sonnenfeld, M., 1997. Parameters controlling sonic velocities in a mixed carbonate-siliciclastics Permian shelf-margin (upper San Andres formation, Last Chance Canyon, New Mexico), Geophysics, 62, 505-520.

Kleipool, L.M., De Jong, K., De Vaal, E.L. \& Reijmer, J.J.G., 2017. Seismic characterization of switching platform geometries and dominant carbonate producers (Miocene, Las Negras, Spain), Sedimentology, 64, 16761707.

Koufos, G.D., Kostopoulos, D.S., Vlachou, T.D. \& Konidaris, G.E., 2011. A synopsis of the late Miocene Mammal Fauna of Samos Island, Aegean Sea, Greece, Geobios, 44, 237-251.

Machek, M., Kalvoda, L., Hladil, J., Roxerová, Z., Vratislav, S., Drahokoupil, J. \& Ryukhtin, V., 2018. Petrophysical record of evolution of weakly deformed low-porosity limestone revealed by small-angle neutron scattering, neutron diffraction and AMS study, Geophys. J. Int., 215(2), 895-908.

Mavko, G., Mukerji, T. \& Dvorkin, J.(2009) The Rock Physics Handbook: Tools for Seismic Analysis of Porous Media, p. 524, Cambridge Univ. Press, Cambridge, U.K

Mbidia Yem, L., Camera, L., Mascle, J. \& Ribodetti, A., 2011. Seismic stratigraphy and deformational styles of the offshore Cyrenaica (Libya) and bordering Mediterranean Ridge, Geophys. J. Int., 185(1), 65-77.

Owen, R.B., Renaut, R.W. \& Stamatakis, M.G., 2011. Late Miocene lacustrine sedimentation in the Mytilinii Basin, Samos Island, Greece, $J$. Paleolimnol., 46, 151-166.

Pe-Piper, G. \& Piper, D.J.W., 2007. Late Miocene igneous rocks of Samos: the role of tectonism in petrogenesis in the southeastern Aegean, in The Geodynamics of the Aegean and Anatolia, vol. 291, pp. 75-97, eds. Taymaz, T. Yimaz, Y. \& Dilek, Y., Geol. Soc. Spec. Publ.

Platt, N.H. \& Whright, V.P., 1991. Lacustrine carbonates: facies models, facies distributions and hydrocarbon aspects, in Lacustrine Facies Analysis, pp. 57-74, eds. Anadón, P. Cabrera, L. \& Kelts, K., International Association of Sedimentologists (I.A.S.) Special Publication 13, Blackwell Scientific Publications, Oxford.

Purser, B.H., 1980. Sédimentation et diagenèse des carbonates néritiques récents; les éléments de la sédimentation et de la diagenèse, p. 388, Ed. Technip.

Rafavich, F., Kendall, C.H.St.C. \& Todd, T.P., 1984. The relationships between acoustic properties and the petrographic character of carbonate rocks, Geophysics, 49, 1622-1636. 
Raymer, L.L., Hunt, E.R. \& Gardner, J.S., 1980. An improved sonic transit time-porosity transform. SPWLA twenty-first annual logging symposium, July 8 - 11, Lafayette, Louisiana.

Regnet, J.B., Fortin, J., Nicolas, A., Guéguen, Y. \& Pellerin, M., 2019. Elastic properties of continental carbonates: From controlling factors to an applicable model for acoustic-velocity predictions, Geophysics, 84(1), MR45-MR59.

Ring, U., Laws, S. \& Bernet, M., 1999. Structural analysis of a complex nappe sequence and late-orogenic basins from the Aegean Island of Samos, Greece, J. Struct. Geol., 21, 1575-1601.

Soete, J. et al., 2015. Acoustic properties in travertines and their relation to porosity and pore types, Mar. Petrol. Geol., 59, 320-335.

Stamatakis, M.G., Hein, J.R. \& Magganas, A.C., 1989. Geochemistry and diagenesis of Miocene lacustrine siliceous sedimentary and pyroclastic rocks, Mytilinii Basin, Samos Island, Greece, Sed. Geol., 64, 65-78.

Steinen, R.P., 1978. On the diagenesis of lime mud; scanning electron microscopic observations of subsurface material from Barbados, W.I., J. Sed. Petro., 48(4), 1139-1148.

Swirydczuk, K., Wilkinson, B.H. \& Smith, G.R.(1979) The Pliocene Glenns Ferry Oolite: lake-margin carbonate deposition in the southwestern Snake river Plain. J. Sed. Petro., 49, 995-1004.
Vail, P.R., Mitchum, R.M., Jr. \& Thomson, S., 1977. Seismic stratigraphy and global changes of sea level, in Seismic stratigraphy - Applications to hydrocarbon exploration. pp. 49-212, ed. Payton, C.E., AAPG Memoir 26.

Wagner, P.D., 1997. Seismic signatures of carbonate diagenesis, in Carbonate Seismology. pp. 307-320, eds. Palaz, I. \& Marfurt, K.J., Geophysical Development Series, No. 6, SEG.

Weger, R.J., Baechle, G.T., Eberli, G.P., Massaferro, J.L. \& Sun, Y.F., 2009. Quantification of pore structure and its effect on sonic velocity and permeability in carbonates, AAPG Bull., 93, 1297-1317.

Weidmann, M., Solounias, M., Drake, R.E. \& Curtis, G. H., 1984. Neogene stratigraphy of the eastern basin, Samos Island, Greece, Geobios, 17, 477-490.

Wyllie, M.R.J., Gregory, A.R. \& Gardner, L.W., 1956. Elastic wave velocities in heterogeneous and porous media, Geophysics, 21, 41-70.

Zeller, M., Reid, S.B., Eberli, G.P., Weger, R.J. \& Massaferro, J.L., 2015. Sequence architecture and heterogeneities of a field-Scale Vaca Muerta analog (Neuquén Basin, Argentina) - from outcrop to synthetic seismic, Mar. Petrol. Geol., 66, 829-847. 


\section{Key words}

\begin{tabular}{|c|c|c|}
\hline COMPOSITION and PHYSICAL PROPERTIES & Seismic cycle & Instability analysis \\
\hline Composition and structure of the continental crust & Space geodetic surveys & Interferometry \\
\hline Composition and structure of the core & Tides and planetary waves & Inverse theory \\
\hline Composition and structure of the mantle & Time variable gravity & Joint inversion \\
\hline Composition and structure of the oceanic crust & Transient deformation & Neural networks, fuzzy logic \\
\hline Composition of the planets & & Non-linear differential equations \\
\hline Creep and deformation & GEOGRAPHIC LOCATION & Numerical approximations and analysis \\
\hline Defects & Africa & Numerical modelling \\
\hline Elasticity and anelasticity & Antarctica & Numerical solutions \\
\hline Electrical properties & Arctic region & Persistence, memory, correlations, clustering \\
\hline Equations of state & Asia & Probabilistic forecasting \\
\hline Fault zone rheology & Atlantic Ocean & Probability distributions \\
\hline Fracture and flow & Australia & Self-organization \\
\hline Friction & Europe & Spatial analysis \\
\hline High-pressure behaviour & Indian Ocean & Statistical methods \\
\hline Magnetic properties & Japan & Thermobarometry \\
\hline Microstructure & New Zealand & Time-series analysis \\
\hline Permeability and porosity & North America & Tomography \\
\hline Phase transitions & Pacific Ocean & Waveform inversion \\
\hline Plasticity, diffusion, and creep & South America & Wavelet transform \\
\hline GENERAL SUBJECTS & GEOMAGNETISM and ELECTROMAGNETISM & PLANETS \\
\hline Core & Archaeomagnetism & Planetary interiors \\
\hline Gas and hydrate systems & Biogenic magnetic minerals & Planetary volcanism \\
\hline Geomechanics & Controlled source electromagnetics (CSEM) & \\
\hline Geomorphology & Dynamo: theories and simulations & SEISMOLOGY \\
\hline Glaciology & Electrical anisotropy & Acoustic properties \\
\hline Heat flow & Electrical resistivity tomography (ERT) & Body waves \\
\hline Hydrogeophysics & Electromagnetic theory & Coda waves \\
\hline Hydrology & Environmental magnetism & Computational seismology \\
\hline Hydrothermal systems & Geomagnetic excursions & Controlled source seismology \\
\hline Infrasound & Geomagnetic induction & Crustal imaging \\
\hline Instrumental noise & Ground penetrating radar & Earthquake dynamics \\
\hline Ionosphere/atmosphere interactions & Magnetic anomalies: modelling and & Earthquake early warning \\
\hline Ionosphere/magnetosphere interactions & interpretation & Earthquake ground motions \\
\hline Mantle processes & Magnetic fabrics and anisotropy & Earthquake hazards \\
\hline Ocean drilling & Magnetic field variations through time & Earthquake interaction, forecasting, \\
\hline Structure of the Earth & Magnetic mineralogy and petrology & and prediction \\
\hline Thermochronology & Magnetostratigraphy & Earthquake monitoring and test-ban \\
\hline Tsunamis & Magnetotellurics & treaty verification \\
\hline Ultra-high pressure metamorphism & Marine electromagnetics & Earthquake source observations \\
\hline Ultra-high temperature metamorphism & Marine magnetics and palaeomagnetics & Guided waves \\
\hline & Non-linear electromagnetics & Induced seismicity \\
\hline GEODESY and GRAVITY & Palaeointensity & Interface waves \\
\hline Acoustic-gravity waves & Palaeomagnetic secular variation & Palaeoseismology \\
\hline Earth rotation variations & Palaeomagnetism & Rheology and friction of fault zones \\
\hline Geodetic instrumentation & Rapid time variations & Rotational seismology \\
\hline Geopotential theory & Remagnetization & Seismic anisotropy \\
\hline Global change from geodesy & Reversals: process, time scale, & Seismic attenuation \\
\hline Gravity anomalies and Earth structure & magnetostratigraphy & Seismic instruments \\
\hline Loading of the Earth & Rock and mineral magnetism & Seismic interferometry \\
\hline Lunar and planetary geodesy and gravity & Satellite magnetics & Seismicity and tectonics \\
\hline Plate motions & & Seismic noise \\
\hline Radar interferometry & GEOPHYSICAL METHODS & Seismic tomography \\
\hline Reference systems & Downhole methods & Site effects \\
\hline Satellite geodesy & Fourier analysis & Statistical seismology \\
\hline Satellite gravity & Fractals and multifractals & Surface waves and free oscillations \\
\hline Sea level change & Image processing & Theoretical seismology \\
\hline
\end{tabular}


Tsunami warning

Volcano seismology

Wave propagation

Wave scattering and diffraction

\section{TECTONOPHYSICS}

Backarc basin processes

Continental margins: convergent

Continental margins: divergent

Continental margins: transform

Continental neotectonics

Continental tectonics: compressional

Continental tectonics: extensional

Continental tectonics: strike-slip and transform

Cratons

Crustal structure

Diapirism

Dynamics: convection currents, and mantle plumes

Dynamics: gravity and tectonics

Dynamics: seismotectonics

Dynamics and mechanics of faulting

Dynamics of lithosphere and mantle

Folds and folding

Fractures, faults, and high strain deformation zones

Heat generation and transport
Hotspots

Impact phenomena

Intra-plate processes

Kinematics of crustal and mantle deformation

Large igneous provinces

Lithospheric flexure

Mechanics, theory, and modelling

Microstructures

Mid-ocean ridge processes

Neotectonics

Obduction tectonics

Oceanic hotspots and intraplate volcanism

Oceanic plateaus and microcontinents

Oceanic transform and fracture zone processes

Paleoseismology

Planetary tectonics

Rheology: crust and lithosphere

Rheology: mantle

Rheology and friction of fault zones

Sedimentary basin processes

Subduction zone processes

Submarine landslides

Submarine tectonics and volcanism

Tectonics and climatic interactions

Tectonics and landscape evolution

Transform faults

Volcanic arc processes
VOLCANOLOGY

Atmospheric effects (volcano)

Calderas

Effusive volcanism

Eruption mechanisms and flow emplacement

Experimental volcanism

Explosive volcanism

Lava rheology and morphology

Magma chamber processes

Magma genesis and partial melting

Magma migration and fragmentation

Mud volcanism

Physics and chemistry of magma bodies

Physics of magma and magma bodies

Planetary volcanism

Pluton emplacement

Remote sensing of volcanoes

Subaqueous volcanism

Tephrochronology

Volcanic gases

Volcanic hazards and risks

Volcaniclastic deposits

Volcano/climate interactions

Volcano monitoring

Volcano seismology 